FLAVONOID BIOSYNTHESIS

LAURA

IN BILBERRY (VACCINIUM

MYRTILLUS L.)

JAAKOLA

Department of Biology,

University of Oulu

OULU 2003

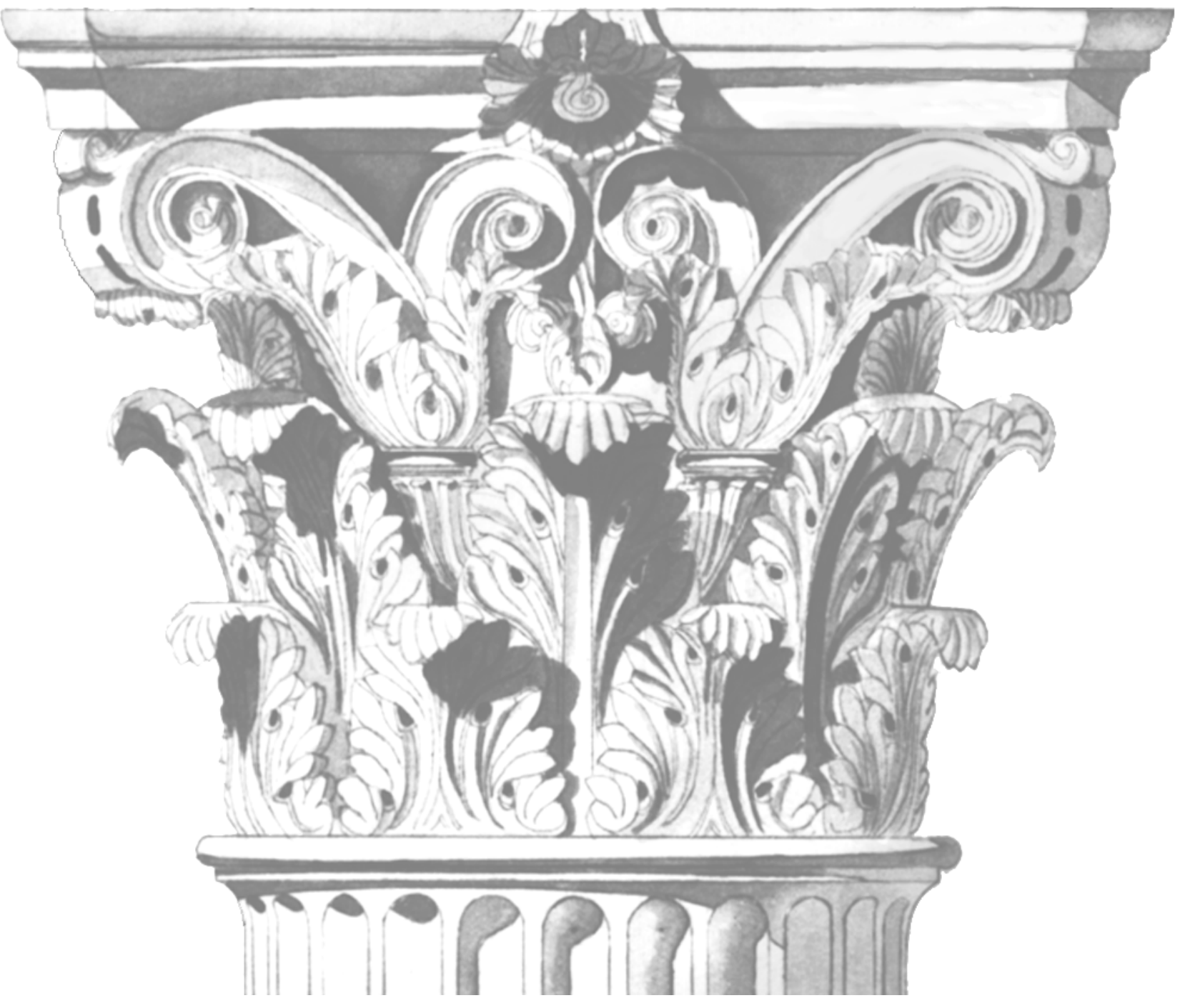



LAURA JAAKOLA

\section{FLAVONOID BIOSYNTHESIS IN BILBERRY (VACCINIUM MYRTILLUS L.)}

Academic Dissertation to be presented with the assent of the Faculty of Science, University of Oulu, for public discussion in Kuusamonsali (Auditorium YB2l0), Linnanmaa, on November 2 Ist, 2003, at 12 noon. 
Copyright (C) 2003

University of Oulu, 2003

Reviewed by

Professor Howard Davies

Docent Kirsi-Marja Oksman-Caldentey

ISBN 95 I-42-7I59-9 (URL: http://herkules.oulu.fi/isbn95 I 427 I599/)

ALSO AVAILABLE IN PRINTED FORMAT

Acta Univ. Oul. A 404, 2003

ISBN 95।-42-7I 58-0

ISSN 0355-3191

(URL: http://herkules.oulu.fi/issn03553।9I/)

OULU UNIVERSITY PRESS

OULU 2003 
Jaakola, Laura, Flavonoid biosynthesis in bilberry (Vaccinium myrtillus L.)

Department of Biology, University of Oulu, P.O.Box 3000, FIN-90014 University of Oulu, Finland Oulu, Finland

2003

\begin{abstract}
Flavonoids are a class of secondary metabolites in plants that are involved in many important functions. Various flavonoid compounds have also been reported to be beneficial for human health. Bilberry (Vaccinium myrtillus L.) is the characteristic field layer species in boreal forests and the fruits of bilberry are rich in anthocyanin pigments, a subclass of flavonoids. In the present work, flavonoid biosynthesis was examined in different tissues of bilberry. The focus was on the developing fruits of wild type and natural color mutants of bilberry, and on effect of solar radiation on flavonoid biosynthesis in bilberry leaves.

For the isolation of RNA for gene expression analysis, a method was optimized for different tissues of bilberry. The cDNA fragments of five genes from the flavonoid pathway, coding phenylalanine ammonia-lyase, chalcone synthase, flavanone 3-hydroxylase, dihydroflavanol 4reductase and anthocyanidin synthase, were isolated from bilberry using polymerase chain reaction technique, sequenced, and labelled with dioxigenin-dUTP label. These homologous, bilberry-specific probes were used for determining the expression of the flavonoid pathway genes in bilberry fruits, flowers and leaves with a modified non-radioactive method developed in the course of the study. The anthocyanins, catechins, proanthocyanidins, flavonols and hydroxycinnamic acids in fruits, leaves and different fractions of bilberry were identified and quantified with high-performance liquid chromatography combined with a diode array detector and mass spectrometer.

The results demonstrate a correlation between anthocyanin accumulation and expression of the flavonoid pathway genes during the ripening of berries. A correlation between flavonol and anthocyanin biosynthesis was detected in bilberry and also in previous literature collected from flavonol and anthocyanin analyses from other fruits. Accordingly, models for the connection between flavonol and anthocyanin synthesis in fruit species were suggested. Activation of the expression of flavonoid pathway genes and accumulation of flavonoids and hydroxycinnamic acids was detected in leaves growing under direct solar radiation, compared to the shadow leaves of the same plants. Based on the results, it is suggested that cyanidin of anthocyanins and flavonol quercetin play a predominant role in the defence against high solar radiation in Vaccinium leaves.

The results give new information about the biosynthesis of flavonoids in bilberry at the gene level, in addition to the information of the composition and content of flavonoids during fruit development and in different parts of the bilberry plant. Also, new information was obtained of the roles of flavonoids in protecting plants from excess solar radiation.
\end{abstract}

Keywords: anthocyanins, bilberry, flavonols, gene expression, hydroxycinnamic acids, proanthocyanidins, Vaccinium myrtillus 



\section{Acknowledgements}

The present work was carried out at the Department of Biology/Botany at the University of Oulu. This study was supported financially by the Emil Aaltonen Foundation, Oscar Öflund Foundation, Jenny and Antti Wihuri Foundation, Kone Foundation, Finnish Cultural Foundation (Northern Ostrobothnia fund), Tauno Tönning Foundation, the Northern Environmental Recearch Network (NorNet), the University of Oulu and by the Faculty of Science of the University of Oulu, which are all gratefully acknowledged. The research was a part of the co-operation Program of the University of Oulu and Kuusamo Town and was also financed by EU (ESF), Regional Council of Northern Ostrobothnia and Kuusamo Town and by the Academy of Finland/SUNARE project (Sustainable Use of Natural Resources, grant no. 52741).

I am most grateful to my supervisors, Professor Anja Hohtola and Professor Sirpa Kärenlampi, for their guidance and encouragement throughout the work. Anja is thanked especially for her kind, friendly and consoling attitude in helping to solve the scientific and the everyday problems. Special thanks to Sirpa for the careful revision of the thesis. I am also grateful to the official referees, Professor Howard Davies (Scottish Crop Research institute, Scotland) and Docent Kirsi-Marja Oksman-Caldentey (VTT Technical Research center of Finland, Espoo) for their valuable comments of this thesis. Cindy Ruuskanen is warmly thanked for revising the language of the thesis and of the original papers.

I express my special thanks to Kaisu Määttä-Riihinen and Professor Riitta Törrönen (Institute of Applied Biotechnology, University of Kuopio) for the pleasant and productive collaboration with the flavonoid analyses. I also thank my other colleagues at our department, Dr. Anna Maria Pirttilä and Minna Halonen for their valuable contributions to this study. Anna Maria is also thanked as an officemate and as a friend for inspiring discussions, encouragement, and for being a "living guidebook" of molecular biology. I am grateful to Professor Teemu Teeri (University of Helsinki) and his Gerbera-group, especially Dr. Paula Elomaa, for kindly offering the primers for $P A L$, CHS, F3H and DFR genes and for useful advice at the beginning of the work. Professor David Percival (Nova Scotia Agricultural College, NS, Canada) is thanked for broadening my knowledge of the world of blueberry production and research during my visit to Nova Scotia in August 2001. 
Several people at the Department of Biology and at the Botanical Gardens are gratefully acknowledged for offering invaluable help. Docent Kari Laine, the Head of the Botanical Gardens, is thanked for his encouragement, advice and for the numerous credentials for my grant applications. Aino Hämäläinen and the technicians of the micropropacation lab as well as both Scientific Curators Ritva Hiltunen and Mirja Siuruainen, Head Gardener Tuomas Kauppila and all the staff of the Botanical Gardens are acknowledged for the helpful attitude. Special thanks also to Taina Uusitalo, Tuulikki Pakonen, Niilo Rankka, Matti Rauman, Kai Niemelä, Ritva Paaso, Hanna-Liisa Suvilampi, Minna Vanhatalo and other people at the Department of Biology for the practical help.

I wish to thank all the plant physiologists and workmates in the present and past for creating pleasant working atmosphere. Terttu Kämäräinen is thanked for her overall helpfulness and especially for, together with Veli-Pekka Pelkonen, making sure that there are no boring days at work. Warm thanks also to Mari Anna Alenius, Zuzana Babincová Zuzsanna György, Soile Jokipii, Merja Hirsikorpi, Professor Hely Häggman, Dr. Anneli Kauppi, Katja Karppinen, Jan Košuth, Janne Koskimäki, Janne Lankila, Dr. Hanna Laukkanen, Professor Pekka Lähdesmäki, Virve Mäntyniemi, Anne Niittyvuopio, Sari Kontunen-Soppela, Tuija Pehkonen, Raili Ruonala, Drs. Erja ja Kari Taulavuori, Dr. Eila Tilman-Sutela, Dr. Anne Tolvanen and Jaana Vuosku for the pleasant company.

The support of friends and family and the moments spent together are warmly acknowledged. I am grateful to my parents, sisters, relatives and my family-in-law for their caring and encouragement. I also thank my husband Ilkka for the support and especially for the great photographs he has taken for my research. My dear sons Iikka and Juuso are thanked for their affection and for keeping me aware of the things that really are important. 


\section{Abbreviations}

ANS

CATB

CHS

DAD

DDBJ

DFR

DIG

EMBL

F3H

GPD

HPLC

PAL anthocyanidin synthase

hexadecyltrimethylammonium bromide

chalcone synthase

diode array detector

DNA Data Bank of Japan

dihydroflavonol 4-reductase

digoxigenin

European Molecular Biology Laboratory

flavanone 3-hydroxylase

glyceraldehyde-3-phosphate dehydrogenase

high-performance liquid chromatography

phenylalanine ammonia-lyase 



\section{List of original papers}

The thesis is based on the following publications, which are referred to in the text by their Roman numerals:

I Jaakola, L., Pirttilä A. M., Halonen M. \& Hohtola, A. (2001) Isolation of high quality RNA from the bilberry (Vaccinium myrtillus L.) fruit. Molecular Biotechnology 19:201-203.

II Jaakola, L., Pirttilä A. M. \& Hohtola A. (2001) cDNA blotting offers an alternative method for gene expression studies. Plant Molecular Biology Reporter. 19:125-128.

III Jaakola, L., Määttä, K., Pirttilä A. M., Törrönen R., Kärenlampi S. \& Hohtola A. (2002) Expression of genes involved in anthocyanin biosynthesis in relation to anthocyanin, proanthocyanidin, and flavonol levels during bilberry fruit development. Plant Physiology 130:729-739.

IV Jaakola, L., Määttä, K., Kärenlampi S. \& Hohtola A. (2003) Activation of flavonoid biosynthesis by solar radiation in bilberry (Vaccinium myrtillus L.) leaves. Manuscript, submitted for publication.

Copyrights:

I Humana Press, II Plant Molecular Biology Reporter, III American Society of Plant Biologists. 



\section{Contents}

Abstract

Acknowledgements

Abbreviations

List of original papers

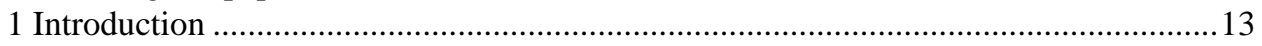

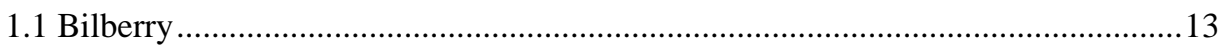

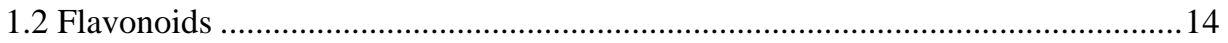

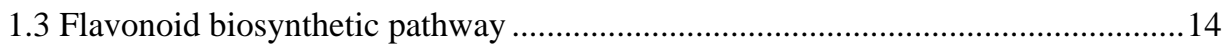

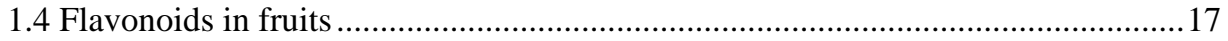

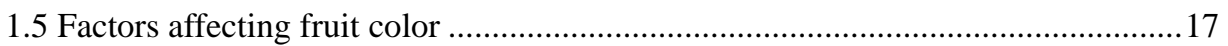

1.6 Environmental significance of flavonoids in plants............................................18

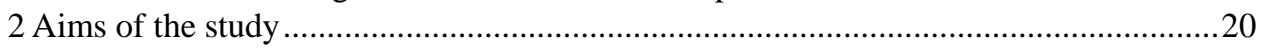

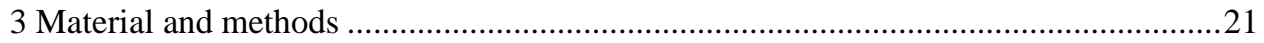

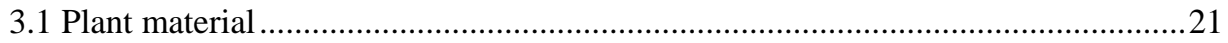

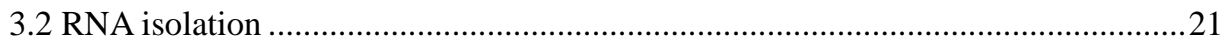

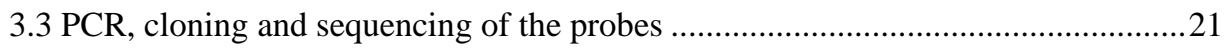

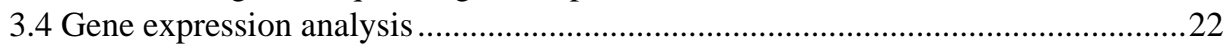

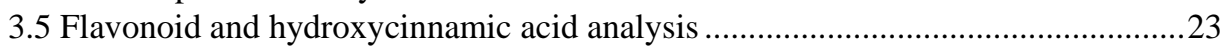

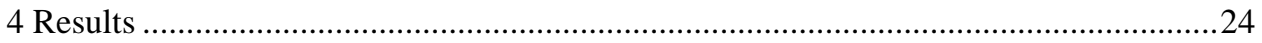

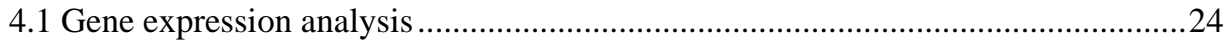

4.1.1 Isolation and sequence analysis of the cDNA fragments of the genes involved in flavonoid biosynthesis ...............................................................24

4.1.2 Expression of the flavonoid pathway genes in fruits .....................................24

4.1.3 Expression of the flavonoid pathway genes in leaves......................................25

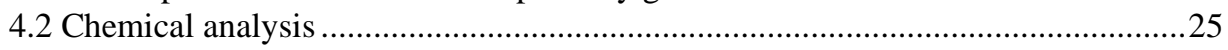

4.2.1 Qualitative and quantitative composition of the flavonoids and

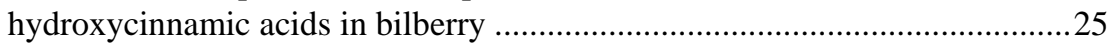

4.2.2 Accumulation of flavonoids during fruit development ..................................25

4.2.3 Effect of high solar radiation on the qualitative and quantitative composition of flavonoids and hydroxycinnamic acids in bilberry leaves ......26 


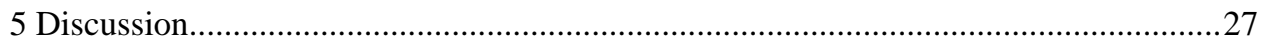

5.1 Biotechnological methods applied to Vaccinium as tools for research ....................27

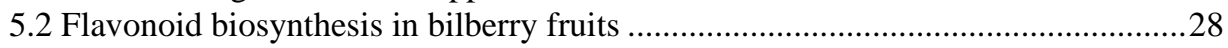

5.3 Effect of solar radiation on flavonoid biosynthesis in bilberry leaves .....................31

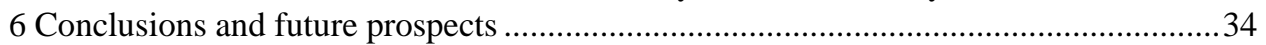

References 


\section{Introduction}

\subsection{Bilberry}

Bilberry, or European blueberry (Vaccinium myrtillus L.) belongs to the genus Vaccinium, which is widespread over the world with over 200 species of evergreen and deciduous woody plants varying from dwarf shrubs to trees. The genus Vaccinium includes many economically important cultivated small fruit species, like blueberries and cranberries. Bilberry grows in the area of Europe and Asia, most abundantly in Scandinavia, Eastern Europe and at higher elevations in Southern Europe. Together with lingonberry ( $V$. vitisidaea L.), bilberry is among the most significant wild berries in these areas (Sjörs 1989, Morazzoni \& Bombardelli 1996). The average bilberry yield in Scandinavia has been estimated to be over 500 million kilograms per year, locally over $100 \mathrm{~kg}$ fresh weight per hectare (Sjörs 1989, Salo 1995). The aroma of bilberry is regarded as special and delicious, differing from other blueberries.

Bilberry is a deciduous dwarf shrub and a characteristic field layer species in boreal forests. Most typically, bilberry grows in Norway spruce (Picea abies) dominated moist upland forests, but it is also found in dryish and grovelike upland forests. According to the third national forest inventory conducted in Finland (1951-53), half of Finland's forest area was covered by bilberry and lingonberry at the field layer level (Salo 1995).

Various ecological, physiological and genetic studies have been conducted on bilberry. Research has been performed on its morphology, growth habit, pollination system, and population dynamics (Flower-Ellis 1971, Sjörs 1989, Jacquemart 1994, Tolvanen 1995, Nuortila et al. 2002). Also, its carbon-, nutrition- and water economy has been explored (Havas 1971, Lähdesmäki et al. 1990, Pakonen et al. 1990, Gerdol et al. 2000, Grelet et al. 2001). Several studies concern the response of bilberry to environmental stress factors like herbivory (Kalela 1957, Laine \& Henttonen 1983, 1987), low temperatures (Taulavuori et al. 1997a), pollution (Taulavuori et al. 1997b, Reimann et al. 2001), and enhanced UV-B radiation (Taulavuori et al. 1998, Phoenix et al. 2000, 2001). The method for tissue culture has been optimized for bilberry (Jaakola et al. 2001) for producing homogenous plant material for research purposes and cultivation. Because of the value of its fruits, interest in cultivation of bilberry is growing. 


\subsection{Flavonoids}

Flavonoids are a class of low-molecular-weight phenolic compounds that are widely distributed in the plant kingdom. Over 6000 naturally occurring flavonoids have been described, and many of them are common in higher plants (Harborne \& Williams 2000). These compounds frequently serve as pigments in plants, but are also involved in many biological interactions. Flavonoids are built upon a $\mathrm{C}_{6}-\mathrm{C}_{3}-\mathrm{C}_{6}$ flavone skeleton in which the three-carbon bridge between the phenyl groups is commonly cyclized with oxygen. Based on the degree of unsaturation and oxidation of the three-carbon segment, flavonoids are divided in several classes (Fig.1A). Most flavonoids reported in the literature are glycosides of a relatively small number of flavonoid aglycons, which are generally water-soluble and accumulate in the vacuoles of plant cells (Bohm 1998, Seigler 1998).

A significant role of flavonoids that has been under very active research recently, is their possible beneficial influence on human health. Flavonoids have been found to own potent antioxidant and free radical scavenging activities in vitro. There is growing evidence from human consumption studies supporting a protective role of flavonoids in cardiovascular diseases and cancer. Many flavonoids have been found to possess antiviral, antibacterial, antifungal or anti-allergenic properties. However, because of the wide variety of different flavonoids, their possible interactions with other substances, and the complexity of their metabolism in the human system, more research in this area is still needed (Hertog et al. 1995, Hollman et al. 1996, Peterson \& Dwyer 1988, Ross \& Kasum 2002).

Blueberries, which are a rich source of anthocyanins, have been found to be beneficial for health (Kalt \& Dufour 1997, Smith et al. 2000). The antioxidant capacity of blueberries has been analyzed in several studies (Heinonen et al. 1998, Prior et al. 1998, Kalt et al. 1999, 2000, Kähkönen et al. 2001, Moyer et al. 2002). Also, the anticancer activity of the Vaccinium species (Bomser et al. 1996, Katsube et al. 2003) and the antimicrobial properties of berry phenolics, including those from the Vaccinium species, (Rauha et al. 2000, Puupponen-Pimiä et al. 2001) have been studied in vitro. Cranberry (V. macrocarpon, $V$. oxycoccos) proanthocyanidins have been found to prevent urinary tract infections (Howell et al. 1998, Kontiokari et al. 2001). A study of Youdim et al. (2000) showed the beneficial effects of blueberries on brain functions related to ageing in vivo. Bilberry fruits and leaves were used in folk medicine in Europe already in the Middle Ages (Morazzoni \& Bombardelli 1996). In the US, bilberry has been among the most significant herbs for sale during the recent years (Blumenthal 1999, 2001).

\subsection{Flavonoid biosynthetic pathway}

Flavonoids are synthesized via the phenylpropanoid pathway. Phenylalanine ammonia lyase (PAL) catalyzes the conversion of phenylalanine to cinnamate. PAL also shows activity with converting tyrosine to $p$-coumarate, albeit to a lower efficiency. The cinnamate 4-hydroxylase $(\mathrm{C} 4 \mathrm{H})$ catalyzes the synthesis of $p$-hydroxycinnamate from 
cinnamate and 4-coumarate:CoA ligase (4CL) converts p-coumarate to its coenzyme-A ester, activating it for reaction with malonyl CoA. The flavonoid biosynthetic pathway starts with the condensation of one molecule of 4-coumaroyl-CoA and three molecules of malonyl-CoA, yielding naringenin chalcone. This reaction is carried out by the enzyme chalcone synthase (CHS). Chalcone is isomerised to a flavanone by the enzyme chalcone flavanone isomerase (CHI). From these central intermediates, the pathway diverges into several side branches, each resulting in a different class of flavonoids. Flavanone 3hydroxylase (F3H) catalyzes the stereospecific 3ß-hydroxylation of (2S)-flavanones to dihydroflavonols. For the biosynthesis of anthocyanins, dihydroflavonol reductase (DFR) catalyzes the reduction of dihydroflavonols to flavan-3,4-diols (leucoanthocyanins), which are converted to anthocyanidins by anthocyanidin synthase (ANS). The formation of glucosides is catalyzed by UDP glucose-flavonoid 3-o-glucosyl transferase (UFGT), which stabilize the anthocyanidins by 3-O-glucosylation (Harborne 1994, Bohm 1998). The overview of the flavonoid pathway is presented in Fig 1B. There is evidence that the enzymes involved in flavonoid metabolism might be acting as membrane-associated multienzyme complexes, which has implications on the overall efficiency, specificity, and regulation of the pathway (Stafford 1991, Winkel-Shirley 1999, 2001).

Studies of the flavonoid pathway range from classical genetic analysis of flower color inheritance patterns by Mendel, through the establishment of their chemical structures, to efforts to understand the factors involved in their biochemical synthesis (Bohm 1998). Basic knowledge of the flavonoid biosynthesis was gained from experimental studies using radio-labeled precursors at the end of 1950's. The development of more sophisticated methods in analytical chemistry and enzymology, and later in gene technology, has produced a vast number of studies and detailed information of the flavonoid biosynthesis in several plant species. The flavonoid biosynthetic pathway has been comprehensively reviewed (e.g. by Dooner \& Robbins 1991, Koes et al. 1994, Holton \& Cornish 1995, Mol et al. 1998, Weisshaar \& Jenkins 1998, Winkel-Shirley 2001).

The first gene isolated from the flavonoid biosynthetic pathway was a CHS gene from parsley (Petroselinum hortense) (Kreuzaler et al. 1983). Transcriptional control of the structural genes of the flavonoid biosynthetic pathway has been most intensively studied in relation to the biosynthesis of anthocyanins. Groundbreaking research concerning the expression of the structural and regulatory genes of the flavonoid pathway has been done with maize (Zea mays) (Goff et al. 1990, Taylor et al. 1990, Tonelli et al. 1991), arabidopsis (Arabidopsis thaliana) (Shirley et al. 1992) and with ornamental plants like snapdragon (Antirrhinum majus) (Martin et al.1991), petunia (van der Krol et al. 1988) and gerbera (Elomaa et al. 1993, Helariutta et al. 1993, 1995). Naturally occurring flavonoid mutants and variants, or genetically transformed mutant plants have been important tools in several investigations clarifying the functions of the flavonoid pathway genes (Shirley et al. 1995, Tanaka et al. 1998).

The expression of flavonoid pathway genes in fruit tissues has been studied on grape (Vitis vinifera) (Boss et al. 1996, Kobayashi et al. 2001), citrus (Citrus unshiu Marc.) (Moriguchi et al. 2001), and strawberry plants (Fragaria spp.) (Manning 1998, Aharoni et al. 2001). The scarcity of studies in this area may be due to a difficulty caused by the special features of the fruit tissues, e.g. the richness of different secondary metabolites 
and RNases, which may hinder the easy application of the molecular biological research methods.

A<smiles>Oc1cc2ccccc2[o+]c1-c1ccccc1</smiles>

Anthocyanidins<smiles>OC1Cc2ccccc2OC1c1ccccc1</smiles><smiles>O=c1c(O)c(-c2ccccc2)oc2ccccc12</smiles>

Flavonols

B

Phenylalanine

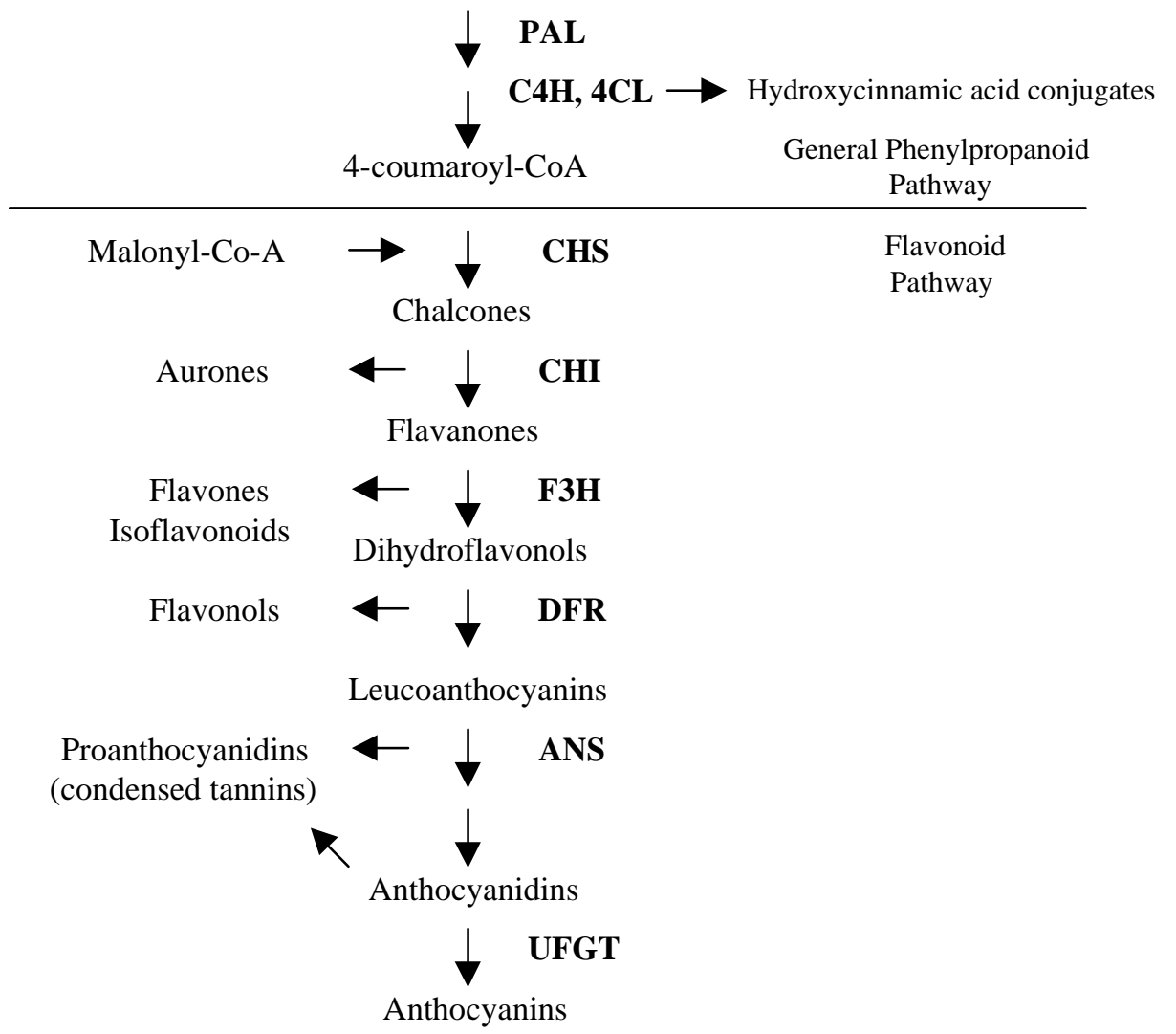

Fig. 1 A) The structures of selected flavonoid classes. B) A schematic presentation of the flavonoid biosynthetic pathway. Enzyme abbreviations: PAL, phenylalanine ammonia-lyase; C4H, cinnamate 4-hydroxylase; 4CL, 4-coumaroyl:CoA ligase; CHS, chalcone synthase; CHI, chalcone isomerase; F3H, flavanone 3-hydroxylase; DFR, dihydroflavonol 4-reductase; ANS, anthocyanidin synthase; UFGT, UDP glucose-flavonoid 3-o-glucosyl transferase. 


\subsection{Flavonoids in fruits}

An important role of flavonoids is to serve as visual signals for animals in attracting pollinators in flowers, and later for animals eating the fruits and thereby helping in seed dispersal. In fruits, flavonoids may contribute in a number of ways to fruit quality, for instance to traits such as color, flavor, bitterness or texture. They are also involved in the formation of undesirable brown pigments in fruits following bruising or cutting and/or storage (Amiot et al. 1997, Robards \& Antolovich 1997).

The composition of flavonoids in different fruit species varies greatly (Macheix et al. 1990, Robards \& Antolovich 1997). Anthocyanins are pigments that give most fruits their red, violet and blue color. The main anthocyanins in fruits are glycosides of six anthocyanidins that are widespread and commonly contribute to the pigmentation of fruits. Cyanidin is the most common anthocyanidin, the others being delphinidin, peonidin, pelargonidin, petunidin and malvidin. Of the flavonols, quercetin, kaempferol, myricetin and isorhamnetin are common in fruits, quercetin being the predominant flavonol. A third predominant flavonoid group in fruits is proanthocyanidins and their monomer units, catechins (procyanidin) or gallocatechins (prodelphinidins), which are the natural substrates of polyphenol oxidases and are, therefore, involved in the browning phenomenon of fruits. Citrus fruits differ in their flavonoid profiles from other fruit species, containing flavanones and flavones that are not common in other fruits.

The development of analytical methods has enabled a more detailed analysis of the qualitative and quantitative composition of the different flavonoids as well as the discovery of new flavonoid compounds. As the flavonoids are widely distributed among plants and show structural diversity due to differences in oxygenation, methylation and glycosylation patterns, and are also chemically fairly stable in plants, they have been used for chemotaxonomy at the species and intraspecific level. In fruit species, flavonoids have been used for chemotaxonomy particularly on genera Ribes, Rubus, Vaccinium and Vitis (Jennings \& Carmichael 1980, Andersen 1987, Goldberg et al. 1998, de Ancos et al. 1999, Kalt et al. 2001). The main flavonoids in Vaccinium fruits are the flavonol quercetin and cyanidin from the anthocyanidins. Also, the flavonol myricetin and delphinidin-derived anthocyanins, namely malvidin and peonidin glucosides are found in many Vaccinium fruits (Macheix et al. 1990, Häkkinen et al. 1999).

\subsection{Factors affecting fruit color}

Factors affecting fruit color are primarily genetically determined. In addition, environmental factors such as nutrients, temperature and light conditions can have an effect on flavonoid composition and on the final hue of the fruit. In addition to flavonoids, carotenoids also give color to fruits. Concerning anthocyanins that are mainly responsible for the bluish to purple and reddish colors in plants, several different factors can affect the final color of the fruit or flower. Delphinidin-derived anthocyanins are known to be responsible for the bluish colors, whereas cyanidin -and pelargonidinderived anthocyanins are found from mauve and reddish tissues, respectively. 
Anthocyanins readily form complexes with so-called co-pigments that can intensify and modify the initial color given by the pigment. Apparently, almost all polyphenols, as well as other molecules, such as purines, alkaloids and metallic cations, have the ability to function as co-pigments. Also, the temperature and $\mathrm{pH}$ of the vacuolar solution may affect the final color (Brouillard \& Dangles 1994, Brouillard et al. 1997, Mol et al. 1998).

The color of bilberries varies normally from blue to almost black. As rare variants, bilberry mutants with white or pink fruits have been found in nature. The change in color in these bilberry mutants might be due to mutations in structural or regulatory genes involved in anthocyanin biosynthesis. Non-pigmented variants are also found from other fruits, typically from grapes or currants, but also, for instance, from raspberries and strawberries.

\subsection{Environmental significance of flavonoids in plants}

In addition to acting as pigments in fruits and flowers, flavonoids are involved in a vast array of other biological functions in plants. They play a crucial role in the symbiotic plant-microbe interactions (nodule formation of nitrogen fixing bacteria in leguminous plants) and in plant sexual reproduction by promoting the pollen tube development (Koes et al. 1994). Flavonoids also have apparent roles in plant stress defense, such as in protection against damage caused by pathogen attack, in wounding or in excess of UVlight. The low availability of nitrogen or phosphorus, and low temperatures affect flavonoid levels in plants (Dixon \& Paiva 1995, Winkel-Shirley 2002). Flavonoids, mainly anthocyanins are responsible for the autumn colors in many plant species; they have been suggested to protect leaf cells from photo-oxidative damage, thereby enhancing the efficiency of nutrient retrieval during senescence (Feild et al. 2001).

From the standpoint of evolution, the protective property flavonoids display against UV-radiation has been suggested to be among the oldest functions of flavonoids in plants. Flavonoids are strongly UV-absorbing compounds, and accumulate mainly in the epidermal cells of plant tissues after UV-induction. Ultraviolet radiation is, by convention, classified into three wavelength ranges: UV-A (320-390 nm), UV-B (280-320 $\mathrm{nm})$, and UV-C $(<280 \mathrm{~nm})$. Radiation reaching the earth is high in the UV-A region, drops sharply in the UV-B region, and drops to nearly zero at $290 \mathrm{~nm}$ (Bohm 1998). UV$\mathrm{B}$ can penetrate the ozone layer in the stratosphere and cause damage to the plants. The epidermal layers of plants can absorb $90-99 \%$ of the incident ultraviolet radiation (Robberecht \& Caldwell 1983). The localization of flavonoids in the epidermal layers of plants and their known ultraviolet absorptive properties has led to a suggestion that they can serve as shields against potentially harmful radiation. There is a growing body of evidence for the role of flavonoids in photoprotection (Winkel-Shirley 2002).

Several studies have demonstrated the change in flavonoid composition of plant leaves as a consequence of excess light or UV-radiation (Lois 1994, Olsson et al. 1998, Hofmann et al. 2000, Tattini et al. 2000, Kolb et al. 2001). The activation of flavonoid biosynthetic genes by UV-radiation has been shown in a number of studies (Logemann et al. 2000). The importance of flavonoids in UV protection has also been proven using 
mutants of Arabidopsis (Li et al. 1993, Landry et al. 1995, Havaux \& Kloppstech 2001) and petunia (Ryan et al. 2002) which have a block in flavonoid production and are, therefore, sensitive to UV-radiation. There is also an Arabidopsis mutant with upregulation of flavonoid pathway genes and elevated accumulation of flavonoids and other phenolics, which is, as a consequence, tolerant against extremely high UV-B levels (Bieza \& Lois 2001). It is evident that the response of various plant species to UVradiation can differ considerably in terms of flavonoid synthesis. (Harborne \& Williams 2000). Interesting questions in this area are how the synthesis of specific flavonoids and other phenolics is regulated in response to UV light in different plant species, how do the flavonoids compare to other phenolics in contributing to UV stress protection, and do the flavonoids have other roles in UV protection beyond the absorption of UV radiation (Winkel-Shirley 2002).

The final composition of flavonoids and other phenolic compounds in fruits and other parts of the plants is determined both genetically and by environmental factors. The composition of these compounds may vary greatly at the species and intra-specific level (Robards \& Antolovich 1997). An interesting and challenging aspect for future research is to clarify the genotype $\mathrm{x}$ environmental interactions on the flavonoid composition in fruit plants. By combining the knowledge gained from the studies concerning the effects of different flavonoid compounds on human health, it might be possible to produce plants with even better health properties. 


\section{Aims of the study}

The main objective of the study was to gain an understanding of the flavonoid biosynthesis in bilberry. Research was focused first on fruit development of the wild-type and the color mutants of bilberry found in nature. Emphasis was also placed on studying the flavonoid biosynthesis in other parts of the plant, and especially in the bilberry leaves. For these purposes, research was carried out:

a) to optimize and develop methods for RNA isolation and gene expression analysis for bilberry (I, II),

b) to isolate and characterize fragments from flavonoid pathway genes from bilberry, for bilberry-specific probes used in gene expression analysis (III),

c) to analyze the qualitative and quantitative composition of flavonoids and cinnamic acids in different tissues of bilberry (III, IV),

d) to analyze the gene expression in relation to accumulation of flavonoids during the fruit development of wild type and in color mutant fruits of bilberry (III), and

e) to analyze the effect of solar radiation on the gene expression and flavonoid and hydroxycinnamic acid compositions in bilberry leaves (IV) 


\section{Material and methods}

\subsection{Plant material}

The flowers and fruits of wild bilberries, growing in the natural forest stands in Oulu, Finland, were harvested at six different stages (I, II, III). The fruits of the color mutation forms of bilberry, i.e. white and pink berries (III), as well as leaf (I, II, IV) and stem samples, were obtained from a test field at the Botanical Garden, University of Oulu. The samples were collected directly into liquid nitrogen and stored at $-70^{\circ} \mathrm{C}$ until used.

\subsection{RNA isolation}

The existing methods were not directly applicable for RNA isolation of bilberry. At the beginning of the work, several methods, developed particularly for RNA isolation from tissues with high phenolic and carbohydrate contents, were tested on bilberry tissues, especially the fruits. Some of the methods were completely unsuccessful, whereas others gave low yields of impure RNA. The CTAB-based RNA isolation method developed for pine trees (Chang et al. 1993) proved to be most suitable for RNA isolation from bilberry, although the yield was still low, and especially the RNA from ripe fruits was contaminated with colored substances. The modification of the CTAB-based RNA isolation procedure for isolating RNA from bilberry fruits and leaf tissues is described in the present study (I).

\subsection{PCR, cloning and sequencing of the probes}

The cDNA was prepared from bilberry fruit total RNA, which was reverse-transcribed by $\mathrm{M}-\mathrm{MuLV}$ reverse transcriptase (Invitrogen, Carlsbad, CA) from an anchored oligo-dT 
primer using standard methods. Fragments of the flavonoid pathway genes and of a glyceraldehyde-3-phosphate dehydrogenase (GPD) gene were amplified from the cDNA by PCR. Partially degenerated primers, originally designed for gerbera, were used for amplifying fragments of PAL, CHS, and DFR coding sequences and of F3H coding sequence. For the amplifying fragment of the ANS and GDP gene coding sequences, primers were designed based on homologies found in genes previously isolated. Primers used in the study are presented in the table 1. Dynazyme DNA-polymerase (Finnzymes, Espoo, Finland) was used for amplification. Conditions for PCR of PAL and CHS fragments were $94{ }^{\circ} \mathrm{C} / 75 \mathrm{~s}, 55^{\circ} \mathrm{C} / 2 \mathrm{~min}, 72{ }^{\circ} \mathrm{C} / 2 \mathrm{~min}, 25$ cycles. For DFR, F3H and ANS fragments, PCR was performed using a "touch down" strategy: 10 times $\left(94{ }^{\circ} \mathrm{C} / 75\right.$ $\mathrm{s} ; 50{ }^{\circ} \mathrm{C} / 5 \mathrm{~min}$ adding $1{ }^{\circ} \mathrm{C}$ per cycle, slope $+22{ }^{\circ} \mathrm{C}$, per $10 \mathrm{~s} ; 72^{\circ} \mathrm{C} / 5 \mathrm{~min}$ ) followed by 31 times $\left(94^{\circ} \mathrm{C} / 75 \mathrm{~s} ; 53^{\circ} \mathrm{C} / 2 \mathrm{~min} ; 72{ }^{\circ} \mathrm{C} / 5 \mathrm{~min}\right)$. The PCR products were cloned into a pUC19 vector (Sambrook and Russel 2001). Sequencing reactions were carried out using a BigDye $^{\mathrm{TM}}$ Terminator Cycle Sequencing Kit (PE Applied Biosystems, Warrington, GB). A DNA Sequencer Model 377 (PE Applied Biosystems) was used for sequencing.

Table 1. A summary of primers used in the study.

\begin{tabular}{lll}
\hline Gene & \multicolumn{1}{c}{ Primers 5’->3’ } & \multicolumn{1}{c}{ Reference } \\
\hline PAL & ACGTGGATCCCA(T/C)GGIGGIAA(T/C)TT(T/C)CA(A/G)GG & $\begin{array}{l}\text { Helariutta } e t \\
\text { al. } 1995\end{array}$ \\
CHS & ACGTGGATCCAC(A/G)TC(T/C)TG(A/G)TT(A/G)TG(TC)TC & AGCAGGATCCAA(A/G)GC(C/T)AT(C/T)AA(A/G)GA(G/A)TGGGG \\
& AGGAGGATCCAAGCAACC(T/C)TG(T/C)TG(A/G)TACATCAT & al. 1995 \\
DFR & CAAAGGATCCGAGAATGAAGT(A/G)AT(A/C/T)AA(A/G)CC & Helariutta et \\
& AGAAGGATCCAAAATACATCCATCC(A/C/G/T)GTCAT & al. 1993 \\
F3H & ACGTGTCGACIGG(T/C)TGIAC(A/C/G/T)GT(T/A/G)ATCCA & III \\
& ACGTCAGCTG(T/C)GA(A/G)GA(T/C)TGGGGIAT(T/C/A)TT & III \\
ANS & T(C/G)CAAA(T/A)GAAGAT(A/C)AACTACTACCC(A/C)A & \\
& CA(G/A)AA(A/G)ACAGCCCA(A/T)GAAA(C/T)CCTIACC & III \\
GPD & GCTCCCAGCAAGGATGCCCC & \\
& CGGAAGGCCATTCCAGTCAACT & \\
\hline
\end{tabular}

\subsection{Gene expression analysis}

As performing the Northern analysis with bilberry RNA using a non-radioactive detection system proved to be difficult, an alternative method for studying the gene expression was developed. The method is based on the use of cDNA instead of RNA for the blotting step (II).

The RNA samples were reverse-transcribed to cDNA directly after isolation. The cDNAs were separated by electrophoresis, stained with ethidium bromide and blotted onto Nylon membrane by Southern transfer. Probes consisting of bilberry-specific PCR amplified fragments of the flavonoid pathway genes were labeled with digoxigenin-dUTP according to manufacturer's instructions (Roche, Mannheim, Germany). Hybridization and detection steps are described detailed in papers II, III and IV. 


\subsection{Flavonoid and hydroxycinnamic acid analysis}

Anthocyanins, catechins, proanthocyanidins, flavonols and hydroxycinnamic acids were identified and quantified from leaves and fruits with high-performance liquid chromatography combined with a diode array detector (III, IV).

Frozen berry and flower samples were crushed and powdered using a mortar and pestle. For leaf and stem samples, the same analysis method was used, but grinding the samples in liquid nitrogen was found to enhance the extraction of flavonoids and hydroxycinnamic acids (IV). Two sub-samples of leaves $(0.25 \mathrm{~g})$ and fruits (1 to $2 \mathrm{~g})$ were weighed and suspended in $10 \mathrm{ml}$ of acidified methanol $(0.6 \mathrm{M}$ of $\mathrm{HCl})$ by heating and mixing for $1 \mathrm{~min}$. After sampling $1 \mathrm{ml}$ of the suspension for anthocyanin analysis, refluxing of the samples was continued. Upon heating in acidic methanol, the flavonol glycosides and anthocyanins were deconjugated to aglycons, and the proanthocyanidins were converted to anthocyanidins. The refluxing time of $2 \mathrm{~h}$ was found previously to be optimal both for flavonol aglycons (Häkkinen et al. 1999) and for anthocyanidins released from proanthocyanidins (Määttä et al. 2001).

The identification and quantification of flavonoids and hydroxycinnamic acids with HPLC combined diode array detection is described in detail by Määttä et al. (2001). The UV-visible spectra of the peaks obtained from berry and leaf extracts were compared to those of available standards for identification and quantified using their response factors. Hydroxycinnamic acids were identified and quantified as $p$-coumaric acid $\left(\lambda_{\max }=310\right.$ $\mathrm{nm})$ and caffeic or ferulic acid $\left(\lambda_{\max }=326 \mathrm{~nm}\right)$ derivatives. Flavonols were identified as myricetin and quercetin $\left(\lambda_{\max }=354 \mathrm{~nm}\right)$ and kaempferol $\left(\lambda_{\max }=348 \mathrm{~nm}\right)$ glycosides and quantified for the weight of quercetin aglycone in rutin (quercetin 3-O-glucosiderhamnoside) (Määttä et al. 2003). Catechins $\left(\lambda_{\max }=278 \mathrm{~nm}\right)$ were identified and quantified using the respective standards of $(+)$-catechin and (-)-epicatechin. The identification and quantification of anthocyanins was based on available anthocyanidin 3$O$-glucosides $\left(\lambda_{\max }=516-524 \mathrm{~nm}\right)$. The anthocyanins from fruits were further identified by HPLC combined electrospray ionization mass spectrometry (ESI-MS). The HPLCESI-MS apparatus and ionization conditions were as described by Häkkinen and Auriola (1998). Acylated anthocyanins showed the spectra similar to the shape and maxima of hydroxycinnamic acid ( $p$-coumaric or caffeic/ferulic acid) and anthocyanin. 


\section{Results}

\subsection{Gene expression analysis}

\subsubsection{Isolation and sequence analysis of the cDNA fragments of the genes involved in flavonoid biosynthesis}

The isolated cDNA fragments of the bilberry flavonoid pathway and GPD genes ranged of size from 171 to $476 \mathrm{bp}$. The nucleotide sequences of all the fragments exhibited 65 to 93\% identity to the corresponding genes from other species. The isolated cDNA fragments of the bilberry flavonoid pathway and GPD genes showing highest homology with genes from other species were selected as probes for the gene expression analysis (III).

\subsubsection{Expression of the flavonoid pathway genes in fruits}

The flavonoid pathway genes were shown to be expressed in two phases during the bilberry fruit development. The genes were highly expressed in flowers and especially at the stages of ripening when the color development occurred. All of the genes examined were expressed both in flowers and in fruits. The expression of CHS and DFR was observable throughout ripening, but was reduced at the early stages of fruit development compared with the later stages of ripening. The expression of the flavonoid pathway genes was highest at stage when the fruit was still pale inside but the skin was already red. In ripe fruits, the expression began to decrease again (III).

The expression of flavonoid pathway genes in the color mutation forms of bilberry was studied at the ripening stage, when the expression in the wild-type bilberries was at its maximum. In both studied color mutants (pink and white), the expression of flavonoid 
pathway genes was reduced compared with the wild-type bilberries. In the pink mutant the expression of the flavonoid pathway genes, except for ANS, was at a detectable level, whereas in the white mutant, only the expression of PAL and DFR was detected (III).

\subsubsection{Expression of the flavonoid pathway genes in leaves}

Increased expression of the flavonoid pathway genes was detected in the leaves growing under direct solar radiation compared with lower leaves of the same plant (IV). The expression of PAL, CHS and F3H was clearly higher in the leaves growing under direct sun exposure, whereas the change in the expression of DFR and ANS genes was lower, but still observable. The expression of all flavonoid pathway genes analyzed was notably higher in the fruits than in the leaves.

\subsection{Chemical analysis}

\subsubsection{Qualitative and quantitative composition of the flavonoids and hydroxycinnamic acids in bilberry}

The composition of flavonoids and hydroxycinnamic acids varied between different tissues of bilberry. Table 2 summarizes the qualitative and quantitative composition of flavonoids and hydroxycinnamic acids detected in this study (III, IV), in addition to new, yet unpublished data of flavonoid and hydroxycinnamic acid composition in bilberry peel, pulp and ground stem tissues. In ripe fruits, anthocyanins were the main flavonoids. The anthocyanin and flavonol contents were notably higher in berry peels than in the berry pulps. In leaves, flavonols and especially quercetin were the main flavonoids. The flavonol composition in fruits was also different from that in leaves, as in addition to quercetin, myricetin is found from fruits and kaempferol from leaves. The hydroxycinnamic acid contents were higher in leaves than in other parts of bilberry. In ground stems, only procyanidins from flavonoids were found in addition to hydroxycinnamic acids.

\subsubsection{Accumulation of flavonoids during fruit development}

At the early stage of the fruit development, procyanidins and quercetin were the major flavonoids, but the levels decreased strongly during the progress of ripening. During the later stages of ripening, the content of anthocyanins increased greatly and they were the 
major flavonoids in the ripe berry. Consistent with anthocyanin accumulation, another flavonol, myricetin, was detected (III, IV). From the two color mutants of bilberry, only proanthocyanidins and quercetin were found.

\subsubsection{Effect of high solar radiation on the qualitative and quantitative composition of flavonoids and hydroxycinnamic acids in bilberry leaves}

The contents of catechins, flavonols and hydroxycinnamic acids were higher in the leaves exposed to direct sunlight. The cyanidin glycosides from anthocyanins were detected only in the leaves growing under direct solar radiation. Of the flavonols, the content of quercetin was threefold in red leaves compared to the green shadow leaves. However, the content of procyanidins was lower in sun exposed leaves, whereas the content of prodelphinins was slightly increased (IV). The qualitative and quantitative composition of flavonoids and hydroxycinnamic acids in green (shadow) and red (sun exposed) bilberry leaves is shown in Table 2.

Table 2. Concentrations $(\mu \mathrm{g} / \mathrm{g})$ of anthocyanins, proanthocyanidins, flavonols and hydroxycinnamic acids in bilberry tissues.

\begin{tabular}{|c|c|c|c|c|c|c|c|c|c|}
\hline & \multirow[b]{2}{*}{$\begin{array}{l}\text { Antho- } \\
\text { cyanins }^{1}\end{array}$} & \multicolumn{2}{|c|}{ Proanthocyanidins } & \multirow[b]{2}{*}{ Myricetin } & \multicolumn{2}{|l|}{ Flavonols } & \multicolumn{2}{|c|}{$\begin{array}{l}\text { Hydroxycinnamic } \\
\text { acids }\end{array}$} & \multirow[t]{2}{*}{ Sum } \\
\hline & & $\begin{array}{c}\text { Pro- } \\
\text { delphinidins }\end{array}$ & $\begin{array}{c}\text { Pro- } \\
\text { cyanidins }\end{array}$ & & Quercetin & Kaempferol & $\begin{array}{c}p- \\
\text { Coumaric }\end{array}$ & $\begin{array}{c}\text { Caffeic or } \\
\text { Ferulic }\end{array}$ & \\
\hline \multicolumn{10}{|l|}{$\begin{array}{l}\text { Bilberry } \\
\text { tissue }\end{array}$} \\
\hline flower & 86 & ND & 50 & ND & 130 & ND & 396 & 587 & 1244 \\
\hline berry & 8010 & NA & NA & 31 & 81 & ND & 65 & 110 & 8297 \\
\hline $\begin{array}{l}\text { berry } \\
\text { peel }\end{array}$ & 20256 & NA & NA & 47 & 159 & ND & 32 & 175 & 20669 \\
\hline $\begin{array}{l}\text { berry } \\
\text { pulp }\end{array}$ & 1040 & NA & NA & 3 & 12 & ND & 100 & 63 & 1218 \\
\hline $\begin{array}{l}\text { green } \\
\text { leaf }\end{array}$ & ND & 25 & 962 & ND & 3369 & 171 & 2989 & 7808 & 15324 \\
\hline red leaf & 882 & 36 & 402 & ND & 10369 & 244 & 6007 & 16249 & 34189 \\
\hline $\begin{array}{l}\text { ground } \\
\text { stem }\end{array}$ & ND & ND & 336 & ND & ND & ND & 778 & 273 & 1387 \\
\hline
\end{tabular}

${ }^{1}$ Quantified anthocyanins were cyanidin glycosides in flowers and leaves, and delphinidin, cyanidin-, petunidin, peonidin-, and malvidinglycosides in peel and pulp of berries. ${ }^{2} \mathrm{NA}=$ not analyzed, $\mathrm{ND}=$ not detected 


\section{Discussion}

\subsection{Biotechnological methods applied to Vaccinium as tools for research}

The beginning of the work showed the challenge of working with fruit tissues and carrying out molecular biological study with new plant material. Applying molecular biological methods to the bilberry demanded a great deal of method testing, optimizing and developing of new ideas, as the existing methods were not directly applicable for the different tissues of bilberry.

The isolation of RNA can often be the bottleneck for the gene expression studies, especially where a fairly large amount of RNA is needed. The factors causing problems are mainly the secondary metabolites that can irreversibly react with nucleic acids and cause problems in subsequent applications (Loomis 1974, John 1992, Levi et al. 1992). Also, the levels of RNase activity can vary between different plant tissues and species. Fruit tissues are regarded to be particularly problematic because of the high levels of phenolic compounds, polysaccharides and elevated levels of RNases (Rodrigues-Pousada et al. 1990, Jones et al. 1997).

For isolating RNA from bilberry, several methods were tested at the beginning of the work. Some of them were completely unsuccessful, whereas others gave low yields of more or less impure RNA. The method described for pine needles (Chang et al. 1993) proved to be most successful, and it was further modified for optimizing the yield and purity of RNA from bilberry. The fruit tissues of bilberry were particularly problematic, and the RNA yields from fruits were constantly lower compared with other tissues, but were still comparable with yields reported for other fruits (Rodrigues-Pousada et al. 1990, Jones et al. 1997, Woodhead et al. 1997). Also, during the DNase treatment of isolated RNA, bilberry RNA degraded more readily compared to RNA isolated with the same method from pine (Pinus sylvestris) needles. Ripe fruits presented additional problems by leaving high residues of colored substances in the isolated RNA. This problem was overcome by additional washing steps with ethanol after the first precipitation of RNA with lithium chloride. 
Also, performing the northern blot analysis with bilberry samples using a nonradioactive detection system proved to be extremely difficult. As the reverse transcription of the bilberry RNA succeeded without problems, it was decided to test cDNA in the blotting procedure instead of RNA (II). Even the preliminary results showed the capacity and function of the method. The cDNA is known to be more stable than RNA. The advantage of this method is that the samples transcribed to cDNA can be stored for longer periods in the freezer compared to RNA, which is known to degrade during storage, even in temperatures below $-70{ }^{\circ} \mathrm{C}$. In addition, with the cDNA blotting method the steps of gel electrophoresis, blotting, hybridization and detection can be done without using hazardous and expensive chemicals, and also without time-consuming handling of the glassware and equipment to eliminate the RNase activity. An advantage is also the possibility to work without radio-labeled probes.

The cause of the problems in conventional northern blotting using the non-radioactive digoxigenin-based detection system might have been the possible minor residues of secondary metabolites bound to the RNA samples, because transcription of the RNA to cDNA solved the problem. These possible residues still did not interfere with the enzyme activity during reverse-transcription. The non-radioactive DIG labeling method is based on a digoxigenin steroid isolated from Digitalis plants. The digoxigenin is linked to the C-5 position of uridine nucleotides via a spacer arm containing eleven carbon atoms. For the visualization, the alkaline phosphatase conjugate generates light with the chemiluminescent substrate (Leitch and Heslop-Harrison 1994, Sambrook and Russel 2001). The same non-radioactive hybridization system has been found to give varying results in studies with other plants containing phenolics. In the study of endophytic fungi (Pirttilä et al. 2003), problems were met in obtaining signals from dot blot analysis with the DIG system when using the DNA of the pink yeast Rhodotorula. When the genomic region of interest was first amplified with PCR, the dot blot analysis succeeded without problems (Pirttilä AM, oral communication).

\subsection{Flavonoid biosynthesis in bilberry fruits}

Fruit development and maturation of fruit tissues represent a final phase of floral development typically proceeding by successful pollination. The first phases after fertilization include the division and the expansion of the cells. Ripening phase is initiated after seed maturation has been completed. Tissue softening and accumulation of flavor compounds, aromatic volatiles and pigments occur during the ripening phase (Brady 1987, Gillaspy et al. 1993). Because of the dual role of non-dehiscent (fleshy) fruits as a part of the plant life cycle, and as an important element of human diet, the molecular basis of development and ripening of fruits has received considerable attention in recent years. The most important species regarding the study of the regulation of fruit development at the molecular level, are tomato (Lycopersicon esculentum), Arabidopsis and, to a lesser extent, strawberry (Fragaria spp.) (Manning 1994, 1998, Moyano et al. 1998, Ronen et al. 1999, for review, see Giovannoni 2001). Although a great deal of information is already available about the different aspects of fruit development, much 
still remains to be learned, especially with species other than the model plants. An aspiring goal is to understand how the collection of otherwise unrelated pathways and processes is coordinated to act efficiently and synchronously during the stages of fruit development (Giovannoni 2001).

The biochemical and physiological changes during fruit development of blueberries have been examined earlier (Young 1951, Edwards et al. 1970), also having a special emphasis on anthocyanin accumulation (Suomalainen \& Keränen 1961, Wang et al. 2000). There are, however, no previous studies on flavonoid biosynthesis in blueberries at the gene level. Concerning Vaccinium species, cDNA encoding DFR has been cloned from cranberry (V. macrocarpon Ait.) (Polashock et al. 2002).

The development of bilberries from flower to ripe fruit lasts usually 8 to 10 weeks, varying between years (Sjörs 1989). During the ripening phase, which lasts 2 to 3 weeks, the accumulation of anthocyanins is rapid. For studying the biosynthesis of flavonoids during bilberry fruit development, cDNA fragments of five structural genes from flavonoid pathway were isolated from bilberry fruits in the present study (III). Fragments were sub-cloned and sequenced for detecting the similarity with the corresponding genes from other species. The expression of flavonoid pathway genes was found to be consistent with the accumulation of flavonoids during fruit development. The way the flavonoid pathway genes in the present study were expressed at the very beginning of the bilberry fruit development, and again at the end of ripening, is similar to what has been observed in the strawberry (Manning 1998) and in grapes (Boss et al. 1996, Kobayashi et al. 2001).

The profile of anthocyanins found in bilberry varied in different parts of the plant (Table 2). The composition of anthocyanins was richest and most varied in fruits, where 15 different anthocyanins were found as glucosides of cyanidins, peonidins, delphinidins, malvidins and petunidins (III). The same anthocyanins were found in bilberry fruit peel and pulp, but the concentration was notably higher in the peel (Table 2). In flowers and leaves, only cyanidin glycosides were found (III, IV). The results obtained in this study provide additional evidence for the correlation between the expression of structural flavonoid pathway genes and anthocyanin accumulation during fruit development. In bilberry fruits, the anthocyanin synthesis occurs first in the epidermal cell layers, after which the inner cells of the fruit also become fully pigmented. The expression of flavonoid pathway genes was specifically up-regulated at the period when anthocyanin accumulation increased most rapidly. In ripe fruits, the expression levels started to lower again. The same phenomenon has been detected in developmental studies of some flowers (Jackson et al. 1992, Quattrocchio et al. 1993, Uimari \& Strömmer 1998).

It was also found that the levels of oligo- and polymeric proanthocyanins were high at the beginning of fruit development (III). This agreed with the results from gene expression analysis as the expression of DFR was detected throughout the fruit development. DFR reduces dihydroflavonols to leucoanthocyanins, which are the precursors of both anthocyanins and proanthocyanidins (Bohm 1998). The contents of proanthocyanidins have also been found to decrease in the progress of ripening in other fruit tissues (Wrangham and Waterman 1983, Boss et al. 1996, Harborne 1997, Mercier 1997). In the present study, the same phenomenon was also detected with the white bilberry mutant (III). The presence of proanthocyanidins in unripe fruit tissues has been suggested to provide protection against being eaten too early, as the taste of 
proanthocyanidins is astringent (Harborne 1997). Proanthocyanidins may also protect the developing fruit tissues against fungal pathogens (Mercier 1997).

The profile of flavonols varies in the different tissues of bilberry. The flavonol quercetin is predominant in all tissues, except in ripe fruits (III). In addition to quercetin, myricetin is found in fruits and kaempferol in leaves. In flowers and the ground stem of bilberry, only quercetin is found. In flowers and fruits, flavonols may act as co-pigments for anthocyanins affecting the shade of the color (Brouillard \& Dangles 1994). Flavonols, especially quercetin, are also known to have protecting roles as UV-filters (WinkelShirley 2002). In the present study, the concentration of quercetin was found to be higher at the beginning of fruit development and in flowers (III). This suggests a role in the protection of the tissues during early fruit development. The content of myricetin increased in consistence with the accumulation of anthocyanins, although at lower levels, which could indicate the role in co-pigmentation.

The color mutant forms of bilberry, with white or pink fruits, analyzed in course of the study (III), showed the reduction in the levels of the expression of flavonoid pathway genes. Likewise, a reduction in the contents of flavonoids was observable. No anthocyanins were detectable in the color mutation forms. Also notable was the absence of myricetin both from pink and white bilberries, which also gives further support for assumption of the possible role of myricetin in co-pigmentation of the wild bilberry fruit. The same phenomenon was detected in the study of phenolic compounds in fruits of black and red currants and their unpigmented green and red variants (Määttä et al. 2003). The composition of the flavonol glycosides was the same, but the content of myricetin glycosides was distinctly lower and those of quercetin glycosides higher in green currants than in black currants.

The appearance of the link between the synthesis of flavonols and anthocyanins, led to the assembly of a summarizing table showing the flavonol and anthocyanin composition of different fruits (III). The data collected showed similar trends observed in other fruits besides bilberry. Accordingly, it was stated that there seems to be three predominant models for flavonol and anthocyanin biosynthesis in fruit tissues. The flavonol quercetin and cyanidin-derived anthocyanins (cyanidin or peonidin glycosides) are found in all fruits, in agreement with the theory that cyanidin glucosides are evolutively more primitive anthocyanins than pelargonidin- or delphinidin- (delphinidin, petudinin or malvidin glucosides) derived anthocyanins (Harborne \& Williams 2000). The trend in fruits seems to be that in addition to the flavonol quercetin and cyanidin glucosides from anthocyanins, either myricetin and delphinidin-derived anthocyanins, or kaempferol and pelargonidin derived anthocyanins are produced. Therefore, it appears that in fruits, FLSs and DFRs are specialized using alternatively either dihydromyricetin or dihydrokaempferol as a substrate, in addition to dihydroquercetin. In flowers, FLSs or DFRs specialized in metabolizing certain flavonols, can also use different dihydroflavonols as substrates to a lesser extent (Holton and Cornish 1995, Bohm 1998, Johnson et al. 2001). Dihydrokaempferol is the precursor of dihydroquercetin and dihydromyricetin and is, therefore, present in all species. This could explain the presence of smaller amounts of kaempferol in species in which quercetin and myricetin are the predominant flavonols (e.g. black currant).

Transcriptional control of flavonoid biosynthesis in fruits is not yet well understood. Aharoni et al. (2001) described the characterization of FaMYB1, a ripening related 
transcription factor from strawberry. When transferring the gene to tobacco, the flowers of tobacco lines expressing FaMYB1 showed a reduction in anthocyanin (cyanidin 3rutinoside) and quercetin glucoside levels. The levels of kaempferol glucosides were, however, not altered. The authors suggested that the transcription factor would have a role in reducing the activity of F3'H (flavonoid 3'-hydroxylase), which catalyzes the formation of dihydroquercetin, the direct precursor of both quercetin and cyanidin. In strawberry, pelargonidin and cyanidin from anthocyanins and kaempferol together with quercetin from flavonols are the main flavonoids in ripe fruit (Häkkinen \& Törrönen 2000, Nyman \& Kumpulainen 2001). The role of FaMYB1 in ripening strawberry could be to coordinately control the pelargonidin-kaempferol:cyanidin-quercetin ratio by suppressing the production of quercetin and cyanidin. Overall, the study of regulation of the flavonoid biosynthesis and other processes in fruit development offers fascinating challenges and possibilities for the future.

\subsection{Effect of solar radiation on flavonoid biosynthesis in bilberry leaves}

As a characteristic field layer species in boreal forests, bilberry is preferably a shade plant and does not tolerate clear cutting, nor the desiccating impact of direct sunlight, well. The thin, wax-free leaves of bilberry have been found to dry up and the crop yield has been found to decrease dramatically after clear cutting (Salo 1995). The decrease in crop yield in clear cutting areas is probably primarily due to dryness, as to some extent, enhanced solar radiation is known to have a positive effect on bilberry fruit production (Hiirisalmi \& Lehmushovi 1989). The effect of enhanced UV-B radiation on growth parameters of sub-arctic heaths, including bilberry, has been explored by Phoenix et al. $(2000,2001)$ in a long-term study. The growth was found to decrease, but the leaf thickness, flowering, and berry production were found to increase under enhanced UV-B radiation. Robakowski (1999) studied the impact of UV-B radiation on the chlorophyll content and chlorophyll fluorescence of bilberry and lingonberry in green house conditions. In bilberry leaves, a reduction in chlorophyll content, as well as in the maximal and steady state fluorescence of chlorophyll, was observed. Semerdjieva et al. (2003) studied the effect of enhanced UV-B radiation on the content and distribution of UV-absorbing phenolic compounds in bilberry, lingonberry and in bog bilberry ( $V$. uliginosum) leaves. The enhanced UV-B radiation increased the concentration of phenolic compounds in all three species, but in bilberry the increase was the highest and these compounds were found to be located throughout the leaf. Lingonberry had the highest concentrations of cell wall bound phenolics in the epidermis, whereas the response of bog bilberry was intermediate between the other two.

When growing on expanse, the upper leaves of bilberry typically turn red. This phenomenon is understood to provide protection against solar radiation (Chalker-Scott, 1999; Winkel-Shirley, 2002). In the present study, the qualitative and quantitative composition of UV-absorbing flavonoids and hydroxycinnamic acids, together with the expression of flavonoid pathway genes, were compared between sun and shadow leaves of bilberry (IV). 
The composition and contents of flavonoids varies a great deal between the different tissues of bilberry. The composition of flavonoids was most simple in ground stems, in which only procyanidins were present in addition to hydroxycinnamic acids. The flavonoid composition in bilberry leaves consists of the flavonols quercetin and kaempferol, of the proanthocyanidins procyanidins and prodelphinidins, in addition to cyanidin glycoside anthocyanins in the red leaves. The concentration of hydroxycinnamic acids is also high in bilberry leaves (Table 1). The composition of flavonoids and hydroxycinnamic acids analyzed in this study from green bilberry leaves was consistent with the previous studies (Pellissier 1993, Gallet 1994, Gallet \& Lebreton 1995, Fraisse et al. 1996, Witzell et al. 2003). Also, the concentrations of flavonols and hydroxycinnamic acids in green bilberry leaves were in accordance with the earlier reports, with the seasonal mean values being 8050 equiv. $\mu \mathrm{g} / \mathrm{g}$ for quercetin, 25000 equiv. $\mu \mathrm{g} / \mathrm{g}$ for caffeic acid and 6500-8100 quercetin equiv. $\mu \mathrm{g} / \mathrm{g}$ for young to old bilberry leaves (Fraisse et al. 1996, Witzell et al. 2003).

The results from the analysis of the leaves of bilberry growing in the shadow or sunlight provide further evidence for the activation of flavonoid biosynthesis as a consequence of solar radiation (IV). The observed increase in the expression of all anthocyanin pathway genes could explain the red colors of the leaves under direct sun exposure. The profile of anthocyanins in red leaves was different from that in fruits, but was similar to the profile analyzed from bilberry flowers (III), as only cyanidin glucosides were found. The protective role of anthocyanins has been suggested in earlier studies (Feild et al. 2001; for review, see Chalker- Scott 1999). In maize, the cultivars with purple leaves were found to be more tolerant against DNA damage caused by UV-B (Stapleton and Walbot 1994). Although anthocyanins were not characterized in the same study, they were speculated to be the same cyanidin glucosides identified earlier in the seed coat of maize (Harborne \& Self 1987, Harborne \& Williams 2000).

From proanthocyanidins, the content of procyanidins in the leaves growing under direct sun exposure was found to be only half of that in the shadow leaves. On the other hand, the contents of catechins, the monomeric units of proanthocyanins, and prodelphinidins were higher in the sun-exposed leaves. Procyanidins are synthetized in the same branch of the flavonoid pathway as cyanidin derived anthocyanins, and they compete for the same substrate. Accordingly, it is possible that in sun exposed bilberry leaves procyanidin production is reduced in favor of the production of cyanidin-derived anthocyanins for protection. Recently, Xie et al. (2003) proved in Arabidopsis the function of BANYULS genes, which encode anthocyanin reductase that converts anthocyanidins to their corresponding 2,3-cis-flavan-3-ols. A mutation in BANYULS genes results in the accumulation of anthocyanins and loss of proanthocyanidins. The results obtained in the present study suggest that in the sun- exposed bilberry leaves, the anthocyanin reductase or leucoanthocyanidin reductase activity is down-regulated to favor the production of anthocyanins for protection (IV). Another possibility is that, in leaves, procyanidins might have a role as storage forms, as the increase of catechins was detected concurrently with the decrease of procyanidins. Overall, the metabolic processes concerning polymeric proanthocyanins are regarded to be very dynamic and under a complex regulatory mechanism (Koupai-Abyazani et al. 1993, Bohm, 1998).

An increase in flavonol production was detected in leaves growing under direct sun exposure (IV). A strong activation of F3H genes was also observed in the same leaves. 
F3H catalyzes hydroxylation of flavanones to dihydroflavonols and is required for the biosynthesis of flavonols, proanthocyanins and anthocyanins (Bohm 1998). As the activation of DFR and ANS genes in the leaves was less prominent, it was assumed that the high expression of $\mathrm{F} 3 \mathrm{H}$ in the leaves exposed to direct sunlight would indicate an increase in the flavonol production. The results from chemical analyses confirmed this assumption, as the content of the flavonol quercetin in the sun-exposed leaves was threefold compared to the shadow leaves. The content of kaempferol was higher in the leaves growing under high solar radiation, although to a lesser degree. An enhanced protective role of quercetin and increased quercetin:kaempferol ratio has been detected in earlier studies with other plants, for instance in transgenic Petunia lines (Ryan et al. 1998, 2002), in Brassica napus (Olsson et al. 1998), and in Trifolium repens (Hofmann et al. 2000).

Hydroxycinnamic acids are the precursors of flavonoids as well as of various other phenylpropanoid metabolites, but they are also involved in the epidermal protection of plant tissues (Landry et al. 1995). In bilberry, the concentrations of conjugated hydroxycinnamic acids were double in the leaves growing under direct solar radiation compared to the shadow leaves. The same phenomenon was observed in Vaccinium corymbosum leaves (unpublished data). In fruits, the concentrations of hydroxycinnamic acids were extensively lower than in other parts of the plant. Hydroxycinnamic acids are known to have the capacity to shield underlying tissues from harmful UV-radiation, but the concentrations of hydroxycinnamic acids were earlier considered to be independent of the plant's light environment (Bornman et al. 1997, Burchard et al. 2000). Kolb et al. (2001) detected an increase in the hydroxycinnamic acid concentrations as a consequence of strong visible radiation in grape leaves, whereas in the same study the flavonoid production was specifically enhanced by UV-radiation. However, the increased concentration of hydroxycinnamic acids in the leaves growing under high solar radiation can partially reflect the overall activation of phenylpropanoid metabolism. 


\section{Conclusions and future prospects}

This thesis and the original papers describe the isolation and characterization of the fragments of several flavonoid pathway genes from bilberry. These fragments represent the first nucleotide sequences of bilberry submitted to GenBank, DDBJ or EMBL databases. The fragments were labeled and used as probes in gene expression analyses. Also described are an improved method for the isolation of RNA from bilberry fruits as well as an alternative method for studying gene expression. The methods developed in this work should also be applicable for other studies where information about gene expression is needed, from bilberry or from other related species.

The expression of flavonoid pathway genes during the bilberry fruit development was found to be consistent with the accumulation of flavonoids. At the early stages of fruit development, quercetin and procyanidins were found to be the main flavonoids, but the levels decreased strongly during the progress of ripening. During the later stages of ripening, the content of anthocyanins increased strongly and these compounds were found to be the major flavonoids in ripe berry besides the flavonol myricetin. The expression of flavonoid pathway genes and the concentrations of flavonoids were found to be reduced in color mutants of bilberry, which explains the change in color from blue to pink or white.

A connection between flavonol and anthocyanin synthesis in bilberry fruits was detected in this study and also in previous literature collected from flavonol and anthocyanin analysis from other fruits. Based on those data, it was concluded that there are three predominant models for flavonol and anthocyanin biosynthesis in fruit tissues. The trend seems to be that in addition to quercetin from flavonols and cyanidin-derived anthocyanins, either myricetin and delphinidin-derived anthocyanins, or kaempferol and pelargonidin-derived anthocyanins are produced.

An activation of flavonoid biosynthesis by solar radiation was detected in bilberry leaves. Expression of all flavonoid pathway genes examined, and changes in the contents of all flavonoids and hydroxycinnamic acids analyzed were detected in bilberry leaves growing under direct sunlight compared with shade leaves. Based on the results, it was suggested that flavonoids more primitive in their evolution, i.e. cyanidin glycosides of anthocyanins and the flavonol quercetin together with hydroxycinnamic acids, play a predominant role in the defense against high solar radiation in Vaccinium leaves. 
Regarding proanthocyanidins, a marked reduction in the procyanidin concentration suggests that they do not have a role in protecting leaf tissues from excess light.

The study of the control of flavonoid biosynthesis in small fruits is in its infancy. Although some information is already gathered, much still remains to be learned. The present study provides both improved methods and new information applicable to fruit plants and flavonoid research. Future research and the accumulation of knowledge, especially about the regulatory systems functional during fruit development and about overall flavonoid biosynthesis, will provide fascinating possibilities for the guidance and modification of metabolic routes in plants, for instance factors such as flavor, color, defense, and health properties. 


\section{References}

Aharoni A, De Vos CHR, Wein M, Zhongkui S, Greco R, Kroon A, Mol JNM \& O’Connell AP (2001) The strawberry FaMYB1 Transcription factor suppresses anthocyanin and flavonol accumulation in transgenic tobacco. Plant J 28: 319-332.

Amiot MJ, Fleuriet A, Cheynier V \& Nicolas J (1997) Phenolic compounds and oxidative mechanism in fruits and vegetables. In Thomas-Barberan F (ed) Phytochemistry of Fruits and Vegetables. Oxford University Press, New York, p 51-85.

Andersen ØМ (1987) Anthocyanins in fruits of Vaccinium japonicum. Phytochemistry 26: 12201221.

Bieza K \& Lois R (2001) An Arabidopsis mutant tolerant to lethal ultraviolet-B levels shows constitutively elevated accumulation of flavonoids and other phenolics. Plant Physiol 126: 11051115 .

Blumenthal M (1999) Market Report. HerbalGram 47: 64-65.

Blumenthal M (2001) Market Report. HerbalGram 55: 60.

Bohm B (1998) Introduction of flavonoids. Harwood Academic Publishers, Singapore.

Bomser J, Madhavi DL, Singletary K \& Smith MAL (1996) In vitro anticancer activity of fruit extracts from Vaccinium species. Planta Medica 62: 212-216.

Bornman JF, Reuber S, Cen Y-P, Weissenböck G (1997) Ultraviolet radiation as a stress factor and the role of protective pigments. In Lumsden, ed, Plants and UV-B: Responses to Environmental Change. Cambridge University Press, Cambridge, NY, pp 157-168.

Boss PK, Davies C \& Robinsson S (1996) Analysis of the expression of anthocyanin pathway genes in developing Vitis vinifera L. cv Shiraz grape berries, and the implications for pathway regulation. Plant Physiol 111: 1059-1066.

Brady CJ (1987) Fruit ripening. Annu. Rev. Plant Physiol 38: 155-178.

Brouillard R \& Dangles O (1994) Flavonoids and flower colour. In: Harborne JB (eds) The Flavonoids: Advances in Research since 1986. Chapman and Hall, London, p 565-588.

Brouillard R, Figueiredo P, Elhabiri M \& Dangles O (1997) Molecular interactions of phenolic compounds in relation to the colour of fruit and vegetables. In Thomas-Barberan F (ed) Phytochemistry of Fruits and Vegetables. Oxford University Press, New York, p 29-49.

Burchard P, Bilger W, Weissenböck G (2000) Contribution of hydroxycinnamates and flavonoids to epidermal shielding of UV-A and UV-B radiation in developing rye primary leaves as assessed by ultraviolet-induced chlorophyll fluorescence measurements. Plant Cell Environ 23:1373-1380.

Chalker-Scott L (1999) Environmental significance of anthocyanins in plant stress responses. Photochem \& Photobiol 70:1-9.

Chang S, Puryear J \& Cairney J (1993) A simple and efficient method for isolating RNA from pine trees. Plant Mol Biol Rep 11: 113-116. 
de Ancos B, Gonzales E, Cano MP (1999) Differentiation of raspberry varieties according to anthocyanin composition. Z Lebensm Unter For 208:33-38.

Dixon RA \& Paiva NL (1995) Stress-induced phenylpropanoid metabolism. Plant Cell 7:10851097.

Dooner HK \& Robbins TP (1991) Genetic and developmental control of anthocyanin biosynthesis. Annu. Rev. Genet. 25:173-199.

Edwards TW, Sherman WB \& Sharpe RH (1970) Fruit development in short and long cycle blueberries. Hort Sci 5: 274-275.

Elomaa P, Honkanen J, Puska R, Seppänen P, Helariutta Y, Mehto M, Kotilainen, M, Nevalainen L \& Teeri TH (1993) Agrobacterium mediated transfer of antisense chalcone synthase cDNA to Gerbera hybrida inhibits flower pigmentation. Bio/Technology 11: 508-511.

Feild TS, Lee DW \& Holbrook NM (2001) Why leaves turn red in autumn. The role of anthocyanins in senescing leaves of red-osier dogwood. Plant Physiol 127: 566-574.

Flower-Ellis JG (1971) Age structure and dynamics in stands of bilberry (Vaccinium myrtillus L.) Ph. D. thesis, Royal College of Forestry, Stockholm, Department of Forest Ecology and Forest Soils, Research Notes 9: 1-108.

Fraisse D, Carnat A \& Lamaison J (1996) Composition polyphénolique de la feuille de myrtille. Ann Pharmaceutiques Francaises 54: 280-283.

Gallet C (1994) Allelopathic potential in bilberry-spruce forests: influence of phenolic compounds on spruce seedlings. J Chem Ecol 20: 1009-1024.

Gallet C \& Lebreton P (1995) Evolution of phenolic patterns in plants and associated litters and humus of a mountain forest ecosystem. Soil Biol Biochem 27: 157-165.

Gerdol R, Iacumin P, Marchesini R \& Bragazza L (2000) Water- and nutrient-use efficiency of a deciduous species, Vaccinium myrtillus and an evergreen species, $V$. vitis-idaea, in subalpine dwarf shrub heath in southern Alps, Italy. Oikos 88:19-32.

Gillaspy G, Ben-David H \& Gruissem W (1993) Fruits: a developmental perspective. Plant Cell 5: 1449-1451.

Giovannoni J (2001) Molecular biology of fruit maturation and ripening. Annu Rev Plant Physiol Plant Mo Biol 52:725-49.

Goff SA, Klein TM, Roth BA, Fromm ME, Cone KC, Radicella JP \& Chandler VL (1990) Transactivation of anthocyanin biosynthesis genes following transfer of $B$ regulatory genes into maize tissues. EMBO J. 9:2517-2522.

Goldberg DM, Karumanchiri A, Tsang E \& Soleas GJ (1998) Catechin and epicatechin concentrations of red wines: regional and cultivar-related differences. Am J Enol Vitic 49:23-34.

Grelet GA, Alexander IJ, Proe MF, Frossard JS \& Millard P (2001) Leaf habit influences nitrogen remobilization in Vaccinium species. J Exp Bot 52: 993-1002.

Harborne JB (1994) The flavonoids, advances in research since 1986. Chapman \& Hall, London.

Harborne JB (1997) Phytochemistry of fruits and vegetables: An ecological overview. In ThomasBarberan F (ed) Phytochemistry of Fruits and Vegetables. Oxford University Press, New York, p 353-367.

Harborne JB \& Self R (1987) Malonated cyanidin 3-glucosides in Zea mays and other grasses. Phytochemistry. 26: 2417-2418.

Harborne JB \& Williams C (2000) Advances in flavonoid research since 1992. Phytochemistry 55: 481-504.

Havas P (1971) The water economy of bilberry (Vaccinium myrtillus) under winter conditions. Rep Kevo Subarctic Res Stat 8:41-52.

Havaux M \& Kloppstech K (2001) The protective functions of carotenoid and flavonoid pigments against excess visible radiation at chilling temperature investigated in Arabidopsis npq and $t t$ mutants. Planta 213:953-966.

Heinonen M, Meyer AS \& Frankel EN (1998) Antioxidant activity of berry phenolics on human low-density lipoprotein and liposome oxidation. J Agric Food Chem 46: 4107-4112.

Helariutta Y, Elomaa P, Kotilainen M, Seppänen P \& Teeri T (1993) Cloning of cDNA coding for dihydroflavonol-4-reductase (DFR) and characterization of $d f r$ expression in the corollas of Gerbera hybrida var. Regina (Compositae) Plant Mol Biol 22: 183-193. 
Helariutta Y, Elomaa P, Kotilainen M, Giersbach RJ, Schröder J \& Teeri TH (1995) Chalcone synthase-like genes active during corolla development are differentially expressed and encode enzymes with different catalytic properties in Gerbera hybrida (Asteraceae). Plant Mol Biol 28: 47-60.

Hertog MG, Kromhout D, Aravanis C, Blackburn H, Buzina R, Fidanza F, Giampaoli S, Jansen A, Menotti A, Nedeljikov S, Pekkarinen M, Simic B, Toshima H, Feskens E, Hollman P \& Katan M (1995) Flavonoid intake and long-term risk of coronary heart disease and cancer in the seven countries study. Arch Intern Med 155: 381-386.

Hiirisalmi H \& Lehmushovi A (1989) Occurrence and utilization of wild Vaccinium species in Finland. Acta Hort. 241: 315-321

Hofmann R, Swinny E, Bloor S, Markham K, Ryan K, Cambell B, Jordan B \& Fountain D (2000) Responses of nine Trifolium repens L. populations to ultraviolet-B radiation: differential flavonol glycoside accumulation and biomass production. Ann Bot 86: 527-537.

Hollman P, Hertog M \& Katan M (1996) Analysis and health effects of flavonoids. Food Chemistry 57: 43-46.

Holton TA \& Cornish EC (1995) Genetics and biochemistry of anthocyanin biosynthesis. Plant Cell 7: 1071-1083.

Howell AB, Vorsa N, Der Marderosian A \& Foo LY (1998) Inhibition of the adherence of pfimbriated Escherichia coli to uroepithelial-cell surfaces by proanthocyanidin extracts from cranberries. N Eng J Med 339: 1085-1086.

Häkkinen SH \& Auriola S (1998) High-performance liquid chromatography with electrospray ionization mass spectrometry and diode array ultraviolet detection in the identification of flavonol aglycones and glycosides in berries. J Chromatogr 829: 91-100.

Häkkinen SH, Kärenlampi SO, Heinonen M, Mykkänen HM \& Törrönen R (1999) Content of flavonols quercetin, myricetin and kaempferol in 25 edible berries. J Agric Food Chem 47: 2274-2279.

Häkkinen SH \& Törrönen R (2000) Content of flavonols and selected phenolic acids in strawberries and Vaccinium species: influence of cultivar, cultivation site and technique. Food Res Int 33:517-524.

Jaakola L, Tolvanen A, Laine K \& Hohtola A (2001) Effect of $\mathrm{N}^{6}$-isopentenyladenine concentration on growth initiation in vitro and rooting of bilberry and lingonberry microshoots. Plant Cell Tiss. Org. Cult. 66:73-77.

Jackson D, Roberts K \& Martin C (1992) Temporal and spatial control of expression of anthocyanin biosynthetic genes in developing flowers of Antirrhinum majus. Plant J 2: 425-434.

Jacquemart A (1994) An isoenzyme study in bilberry (Vaccinium myrtillus) 2. Mating system and genetic structure. Belgian J Bot 127: 105-114.

Jennings DL \& Carmichael E (1980) Anthocyanin variation in the genus Rubus. New Phytol 84: 505-513.

John ME (1992) An efficient method for isolation of RNA and DNA from plants containing polyphenols. Nucleic Acids Res 20:2381.

Johnson ET, Ryu S, Yi H, Shin B Cheong H \& Choi G (2001) Alteration of a single aminoacid changes the substrate specificity of dihydroflavonol 4-reductase. Plant J 25: 325-333.

Jones CS, Iannetta PPM, Woodhead M, Davies HV, McNicol RJ \& Taylor MA (1997) The isolation of RNA from raspberry fruit. Mol Biotech 8: 219-221.

Kalela O (1957) Regulation of reproduction rate in subarctic populations of the vole Clethrionomys rufocanus (Sund.). Ann Acad Sci Fenn 34: 1-60

Kalt W \& Dufour D (1997) Health functionality of blueberries. HortTechnol 7: 216-221.

Kalt W, Forney CF, Martin A \& Prior RL (1999) Antioxidant capacity, vitamin C, phenolics and antocyanins after fresh storage of small fruits. J Agric Food Chem 47: 4638-4644.

Kalt W, McDonald JE \& Donner H (2000) Anthocyanins, phenolics, and antioxidant capacity of processed lowbush blueberry products. Food Chem Toxicol 65: 390-393.

Kalt W, Ryan D, Duy J, Prior R, Ehlenfeldt M \& Kloet V (2001) Interspecific variation in anthocyanins, phenolics, and antioxidant capacity among genotypes of highbush and lowbush blueberries (Vaccinium section cyanococcus spp.) J. Agric Food Chem 49: 4761-4767. 
Katsube N, Iwashita K, Tsushida T, Yamaki K \& Kobori M (2003) Induction of apoptosis in cancer cells by bilberry (Vaccinium myrtillus) and anthocyanins. J Agric Food Chem 50: 519-525.

Koes R, Quattrocchio F \& Mol J (1994) The flavonoid biosynthetic pathway in plants: Function and evolution. BioEssays 16: 123-132.

Kobayashi S, Ishimaru M, Ding CK, Yakushiji H \& Goto N (2001) Comparison of UDPglucose:flavonoid 3-O-glucosyltransferase (UFGT) gene sequences between white grapes (Vitis vinifera) and their sports with red skin. Plant Sci 160: 543-550.

Kolb CA, Käser MA, Kopecký J, Zotz G, Riederer M \& Pfündel EE (2001) Effects of natural intensities of visible and ultraviolet radiation on epidermal ultraviolet screening and photosynthesis in grape leaves. Plant Physiol 127:863-875.

Kontiokari T, Sundqvist K, Nuutinen M, Pokka T, Koskela M \& Uhari M (2001) Randomised trial of cranberry-lingonberry juice and Lactobacillius GG drink for the prevention of urinary tract infections in women. BMJ 322: 1571.

Koupai-Abyazani M, McCallum J, Muir A, Bohm B, Towers G \& Gruber M (1993) Developmental changes in the composition of proanthocyanidins from leaves of sainfoin (Onobrychis viciifolia Scop.) as determined by HPLC analysis. J Agric Food Chem 41: 1066-1070.

Kreuzaler F, Ragg H, Fauz E, Kuhn DN \& Hahlbrock K (1983) UV-induction of chalcone synthase mRNA in cell suspension cultures of Petroselinum hortense. Proc Natl Acad Sci USA 80: 259193.

Kähkönen M, Hopia A \& Heinonen M (2001) Berry phenolics and their antioxidant activity. J Agr Food Chem 49: 4076-4082.

Laine K \& Henttonen H (1983) The role of plant production in microtine cycles in northern Fennoscandia. Oikos 40: 407-418.

Laine K \& Henttonen H (1987) Phenolics/nitrogen ratios in the blueberry Vaccinium myrtillus in relation to temperature and microtine density in Finnish Lapland. Oikos 50:389-395.

Landry LG, Chapple C, Last RL (1995) Arabidopsis mutants lacking phenolic sunscreens exhibit enhanced ultraviolet-B injury and oxidative damage. Plant Physiol 109: 1159-1166.

Leitch IJ \& Heslop-Harrison JS (1994) Detection of digoxigenin labeled DNA probes hybridized to plant chromosomes in situ. In: Isaac PG (eds) Protocols for Nucleic Acid Analysis by Nonradioactive Probes. Methods in Moleculr Biology, vol 28. Humana Press, Totowa, New Jersey p. 177-185.

Levi, A, Galau GA \& Wetztain HY (1992) A rapid procedure for the isolation of RNA from highphenolic-containing tissues of pecan. HortScience 27: 1316-1318.

Li J, Ou-Lee T-M, Raba R, Admundson RG \& Last RL (1993) Arabidopsis flavonoid mutants are hypersensitive to UV-B irradiation. Plant Cell 5: 171-179.

Logemann E, Tavernaro A, Schulz W, Somssich IE \& Hahlbrock K (2000) UV light selectively coinduces supply pathways from primary metabolism and flavonoid secondary product formation in parsley. PNAS 97:1903-1907.

Lois R (1994) Accumulation of UV-absorbing flavonoids induced by UV-B radiation in Arabidopsis thaliana L. Planta 194:498-503.

Loomis WD (1974) Overcoming problems of phenolics and quinones in the isolation of plant enzymes and organelles. Meth Enzymol 31: 528-545.

Lähdesmäki P, Pakonen T, Laine K, Saari E \& Havas P (1990) Environmental factors affecting basic nitrogen metabolism and seasonal levels of various nitrogen fractions in tissues of bilberry, Vaccinium myrtillus. Holarct Ecol 13: 19-30.

Macheix JJ, Fleuriet A \& Billot J (1990) Fruit Phenolics. Boca Raton, FL, CRC Press.

Manning K (1994) Changes in gene expression during strawberry fruit ripening and their regulation by auxin. Planta 194:62-68.

Manning K (1998) Isolation of a set of ripening related genes from strawberry: their identification and possible relationship to fruit quality traits. Planta 205: 622-631.

Martin C, Prescott A, Mackay S, Bartlett J \& Vrijlandt E (1991) Control of anthocyanin biosynthesis in flowers of Antirrhinum majus. Plant J 1: 37-49.

Mercier J (1997) Role of phytoalexins and other antimicrobial compounds from fruits and vegetables in postharvest disease resistance. In Thomas-Barberan F, ed, Phytochemistry of Fruits and Vegetables. Oxford University Press, New York, p 221-241. 
Mol J, Grotewold E \& Koes R (1998) How genes paint flowers and seeds? Trends Plant Sci 3: 212217.

Morazzoni P \& Bombardelli E (1996) Vaccinium myrtillus L. Fitoterapia 67:3-29.

Moriguchi T, Kita M, Tomono Y, Endo-Inagaki T \& Omura M (2001) Gene expression in flavonoid biosynthesis: Correlation with flavonoid accumulation in developing citrus fruit. Physiol Plant 111: 66-74.

Moyano E, Portero-Robles I, Medina-Esco-bar N, Valpuesta V, Muñoz-Blanco J \& Caballero JL (1998) A fruit specific putative dihydroflavonol 4-reductase gene is differentially expressed in strawberry during the ripening process. Plant Physiol 117:711-716.

Moyer RA, Hummer KE, Finn CE \& Wrolstad RE (2002) Anthocyanins, phenolics, and antioxidant capacity in diverse small fruits: Vaccinium, Rubus and Ribes. J Agric Food Chem 50: 519-525.

Määttä K, Kamal-Eldin A \& Törrönen R (2001) Phenolic compounds in berries of black, green and white currants (Ribes sp.). Antioxid Redox Signal 3: 981-993.

Määttä K, Kamal-Eldin A \& Törrönen R (2003) High-performance liquid chromatography (HPLC) analysis of phenolic compounds in berries with diode array and electrospray ionisation mass spectrometric (MS) detection: Ribes species. J Agric Food Chem, In press.

Nuortila C, Tuomi J \& Laine K (2002) inter-parent distance affects reproductive success in two clonal dwarf shrubs, Vaccinium myrtillus and Vaccinium vitis-idaea (Ericaceae)

Nyman A \& Kumpulainen J (2001) Determination of anthocyanins in berries and red wine by highperformance liquid chromatography. J Agric Food Chem 49: 4183-4187.

Olsson LC, Veit M, Weissenböck G \& Bornman JF (1998) Differential flavonoid response to enhanced UV-B radiation in Brassica napus. Phytochemistry 49: 1021-1028.

Pakonen T, Saari E, Laine K, Havas P \& Lähdesmäki P (1990) How do seasonal changes in carbohydrate concentrations in tissues of the bilberry (Vaccinium myrtillus L.) reflect carbon resource allocation patterns? Acta Oecol 12: 249-259.

Pellissier F (1993) Allelopathic effect on phenolic acids from humic solutions of two spruce mycorrhizal fungi: Genococcum graniforme and Laccaria laccata. J Chem Ecol 19: 2105-2114.

Peterson J \& Dwyer J (1998) Flavonoids: dietary occurrence and biochemical activity. Nutrition Research 18: 1995-2018.

Phoenix G, Gwynn-Jones D, Lee J \& Callaghan T (2000) The impacts of UV-B radiation on the regeneration of sub-arctic heath community. Plant Ecol 146: 67-75.

Phoenix G, Gwynn-Jones D, Callaghan T, Sleep D \& Lee J (2001) Effects of global change on subarctic heath: effects of enhanced UV-B radiation and increased summer precipitation. J Ecol 89: 256-267.

Pirttilä AM, Laukkanen H, Pospiech H, Myllylä R \& Hohtola A (2000) Detection of intracellular bacteria in the buds of Scotch pine (Pinus sylvestris L.) by in situ hybridization. Appl Environ Microbiol 66: 3073 - 3077.

Polashock JJ, Griesbach RJ, Sullivan RF \& Vorsa N (2002) Cloning of a cDNA encoding the cranberry dihydroflavonol-4-reductase (DFR) end expression in transgenic tobacco. Plant Sci. 163: 241-251.

Prior RL, Cao G, Martin A, Sofic E, McEwen J, O’Brien C, Lischner N, Ehlenfeldt M, Kalt W, Krewer G \& Mainland M (1998) Antioxidant capacity as influenced by total phenolic and anthocyanin content, maturity, and variety of Vaccinium species. J Agric Food Chem 46: 26862693.

Puupponen-Pimiä R, Nohynek L, Meier C, Kähkönen M, Heinonen M, Hopia A \& OksmanCaldentey KM (2001) Antimicrobial properties of phenolic compounds from berries. J Appl Microbiol 90: 494-507.

Quattrocchio FM, Wing J, Leppen H, Mol J \& Koes R (1993) Regulatory genes controlling anthocyanin pigmentation are functionally conserved among plant species and have distinct sets of target genes. Plant Cell 5: 1497-1512.

Rauha JP, Remes S, Heinonen M, Hopia A, Kähkönen M, Kujala T, Pihlaja K, Vuorela H \& Vuorela P (2000) Antimicrobial effects of Finnish plant extracts containing flavonoids and other phenolic compounds. Int J Food Microbiol 56: 3-12.

Reimann C, Koller F, Kashulina G, Niskavaara H \& Englmaier P (2001) Influence of extreme pollution on the inorganic chemical composition of some plants. Environ Pollut 115: 239-252. 
Robakowski P (1999) Impact of ultraviolet-B radiation on two species of forest dwarf shrubs: bilberry (Vaccinium myrtillus L.) and cowberry (Vaccinium vitis-idaea L.). Polish J Ecol 47: 313.

Robards K \& Antolovich M (1997) Analytical chemistry of fruit bioflavonoids. Analyst 122: 11R34R.

Robberecht R \& Caldwell MM (1983) Protective mechanism and acclimation to solar ultraviolet-B radiation in Oenothera stricta. Plant Cell Environ 6: 477-485.

Rodrigues-Pousada R, Van Montagu M \& Van der Straeten D (1990) A protocol for preparation of total RNA from fruit. Technique 2: 292-294.

Ronen G, Cohen M, Zamir D, Hirschberg J (1999) Regulation of carotenoid biosynthesis during tomato fruit development: Expression of the gene for lycopene epsilon-cyclase is downregulated during ripening and is elevated in the mutant Delta. Plant J 17:341-51.

Ross JA \& Kasum CM (2002) Dietary flavonoids: Bioavailability, metabolic effects, and safety. Annu Rev Nutr 22: 19-34.

Ryan K, Markham K, Bloor S, Bradley M, Mitchell K \& Jordan B (1998) UV-B radiation induces increase in quercetin:kaempferol ratio in wild-type and transgenic lines of Petunia. Photochem Photobiol 68: 323-330.

Ryan K, Swinny E, Markham K \& Winefield C (2002) Flavonoid gene expression and UV photo protection in transgenic and mutant Petunia leaves. Phytochemistry 59: 23-32.

Salo K (1995) Non-timber forest products and their utilization. In Hytönen M (eds) Multiple-use Forestry in the Nordic Countries. Gummerrus Press, Jyväskylä, p 117-155.

Sambrook J \& Russel DW (2001) Molecular cloning: A Laboratory Manual, $3^{\text {rd }}$ ed. Cold Spring Harbor Laboratory Press, Cold Spring Harbor, NY.

Seigler D. (1998) Flavonoids. Plant Secondary metabolism. Kluwer Academic Publishers, Norwell, Massachusetts. p.151-192.

Semerdjieva SI, Sheffield E, Phoenix GK, Gwynn-Jones D, Callaghan TV \& Johnson GN (2003) Contrasting strategies for UV-B screening in sub-Arctic dwarf shrubs. Plant, Cell, Environ. 26:957-964.

Shirley BW, Hanley S, Goodman HM (1992) Effects of ionizing radiation on a plant genome: analysis of two Arabidopsis transparent testa mutations. Plant Cell 4:333-347.

Shirley BW, Kubasek WL, Storz G, Bruggemann E, Koornneef M, Ausubel F \& Goodman HM (1995) Analysis of Arabidopsis mutants deficient in flavonoid biosynthesis. Plant J 8: 659-671.

Sjörs H (1989) Blåbär, Vaccinium myrtillus: ett växtporträtt. Svensk. Bot. Tidskr. 83: 411-428.

Smith MAL, Marley KA, Seigler D, Singletary KW \& Meline B (2000) Bioactive properties of wild blueberry fruits. J Food Sci 65: 352-356.

Stafford H (1991) Flavonoid evolution: An enzymatic approach. Plant Physiol 96: 680-685.

Stapleton AE \& Walbot V (1994) Flavonoids can protect maize DNA from the induction of UV radiation damage. Plant Physiol 105: 881-889.

Suomalainen H \& Keränen A (1961) The first anthocyanins appearing during the ripening of blueberries. Nature 191: 498-499.

Tanaka Y, Tsuda S \& Kusumi T (1998) Metabolic engineering to modify flower color. Plant Cell Physiol 39: 1119-1126.

Tattini M, Gravano E, Pinelli P, Mulinacci N \& Romani A (2000) Flavonoids accumulate in leaves and glandular trichomes of Phillyrea latifolia exposed to excess solar radiation. New Phytol 148:69-77.

Taulavuori K, Laine K, Taulavuori E, Pakonen T \& Saari E (1997a) Accelerated dehardening in the bilberry (Vaccinium myrtillus L.) induced by a small elevation in air temperature. Environ Pollut 98: 91-95.

Taulavuori E, Taulavuori K, Laine K, Pakonen T \& Saari E (1997b) Winter hardening and glutathione status in the bilberry (Vaccinium myrtillus L.) in response to trace gases $\left(\mathrm{CO}_{2}, \mathrm{O}_{3}\right)$ and nitrogen fertilization. Physiol Plant 101: 192-198.

Taulavuori E, Backman M, Taulavuori K, Gwynn-Jones D, Johanson U, Laine K, Callaghan T, Sonesson M \& Bjorn LO (1998) Long-term exposure to enhanced ultraviolet-B radiation in the sub-arctic does not cause oxidative stress in Vaccinium myrtillus. New Phytologist 140:691-697. 
Taylor LP \& Briggs WR (1990) Genetic regulation and photocontrol of anthocyanin accumulation in maize seedlings. Plant Cell 2:115-127.

Tolvanen A (1995) Aboveground growth habits of two Vaccinium species in relation to habitat. Can J Bot 73:177-184.

Tonelli C, Consonni G, Dellaporta SL, Viotti A \& Gavazzi G (1991) Molecular analysis of the maize anthocyanin regulatory locus $\mathrm{Sn}: \mathrm{Bol} 3$, a light independent and tissue specific gene of maize. Mol. Gen. Genet. 199:201-207.

Uimari A \& Strömmer J (1998) Anthocyanin regulation mutants in pea: effects on gene expression and complementation by R-like genes of maize. Mol Gen Genet 257: 198-204.

van der Krol A, Lenting P, Veenstra J, van der Meer I \& Koes R (1988) An antisense chalcone synthase gene in transgenic plants inhibits flower pigmentation. Nature 333: 866-869.

Wang J, Kalt W \& Sporns P (2000) Comparison between HPLC and MALDI-TOF MS analysis of anthocyanins in highbush blueberries. J Agric Food Chem 48: 3330-3335.

Weisshaar B \& Jenkins GI (1998) Phenylpropanoid biosynthesis and its regulation. Curr Opin Plant Biol 1: 251-257.

Winkel-Shirley B (1999) Evidence for enzyme complexes in the phenylpropanoid and flavonoid pathways. Physiol Plant 107: 142-149.

Winkel-Shirley B (2001) Flavonoid biosynthesis. A colorful model for genetics, biochemistry, cell biology and biotechnology. Plant Physiol 126: 485-493.

Winkel-Shirley B (2002) Biosynthesis of flavonoids and effects of stress. Curr Opin Plant Biol 5: 218-223.

Witzell J, Gref R \& Näsholm T (2003) Plant-part specific and temporal variation in phenolic compounds of boreal bilberry (Vaccinium myrtillus) plants. Biochem System. Ecol 31: 115-127.

Woodhead M, Taylor MA, Davies HV, Brennan RM \& McNicol RJ (1997) Isolation of RNA from blackcurrant (Ribes nigrum L.) fruit. Mol Biotech 7: 1-4.

Wrangham RW \& Waterman PG (1983) Condensed tannins in fruits eaten by chimpanzees. Biotropica 15: 217-222.

Xie D, Sharma S, Paiva N, Ferreira D \& Dixon R (2003) Role of anthocyanidin reductase, encoded by BANYULS in plant flavonoid biosynthesis. Science 299: 396-399.

Youdim K, Shukitt-Hale B, Martin A, Wang H, Denisova N, Bickford P \& Joseph J (2000) Shortterm dietary supplementation of blueberry polyphenolics: Beneficial effects on aging brain performance and peripheral tissue function. Nutritional Neurosci 3: 383-397.

Young RS (1951) Growth and development of the blueberry fruit (Vaccinium corymbosum L. and V. angustifolium Ait.). Proc Am Soc Hort Sci 59: 167-172. 